\title{
INTERNAL MIGRATION IN INDONESIA: DESCRIPTIVE NOTES
}

\author{
Geoffrey McNicoll
}

The major reason for the small attention hitherto given to the study of internal migration in Indonesia has been the inadequacy of the relevant statistics. This is a pervasive problem for Indonesian demography; even the estimates of vital rates are open to considerable doubt. However, two new sources of information are now becoming available: the 1961 census and the 1964/65 National Sample Survey. When taken in conjunction with a number of other specialized studies, these provide a body of data which give an overall picture of migratory patterns and make possible some checking for consistency.

The outline of population movements in Indonesia is well known, though for the most part the quantities involved is not. The most obvious flow is that occasioned by the urbanization process; this is especially marked in the movement of people from rural Java to the large cities of that island, particularly Djakarta. The survey of urban migrants in Djakarta carried out by the Economic and Social Research Institute of the University of Indonesia in $1953^{1}$ is still the only detailed treatment of this important phenomenon, and the general significance of its results is limited to some degree by the purposive selection of its sample. In his recent study of Djakarta, ${ }^{2}$ Castles has used data on ethnic groups from the 1930 census and the 1930 and 1961 data on birthplaces to estimate the 1961 ethnic composition of that city, and in the process has illustrated how much useful information can be extracted from such material by the judicious use of assumptions. Outmigration from Java under the government's longstanding transmigration program, largely directed to Lampung province in Sumatra, has also received much attention, not least because of the sociological problems it has raised in the settlement areas. Studies proceeding from this concern include Kampto Utomo's discussion of a Javanese migrant community in Lampung ${ }^{3}$ and Widjojo Nitisastro's detailed population projections based on alternative assumptions of fertility, mortality,

1. H. J. Heeren (ed.), "The Urbanization of Djakarta," Ekonomi dan Keuangan Indonesia (VII, II), 1955, Pp. 1-43.

2. Lance Castles, "The Ethnic Profile of Djakarta," Indonesia (3), April 1967, PP. 153-204.

3. Kampto Utomo, Masjarakat Transmigran Spontan di Daerah W. Sekampung (Lampung) (Djakarta: Penerbitan Universitas, 1958). 
and strategles of outmigration from Java. ${ }^{4}$ Other population movements studied have been the mass migration of Bataks from the Toba highlands in North Sumatra to the (former) East Coast residency in the early 1950's, which Cunningham has described, 5 and the remarkable outmigration from Bawean Island discussed by Vredenbregt. 6 So far, however, no overview of internal migration has been developed which would allow these specific movements to be seen in perspective, and I should like to attempt this here, stressing the movement that has taken place in the post-independence era. I shall begin by discussing the data to be used and the scale of migratory movements contrasted with the total population, and then shall take up specific types of migration: nonrecurrent movements, such as those accompanying the rebellions, long-term secular flows, and urban migration.

It should be stressed that this is in every sense a preliminary study. No broadly adequate description can be undertaken before the fully processed 1961 census data are available, and probably also the results of the next (1970 or 1971) census will be necessary for this. But as even the first of these events is unlikely to take place for several years there is some point in making an interim effort to draw together some of the dispersed information comprising our present knowledge. One important limitation on the attempt is the nature and quality of the available data, which to a considerable extent determine the emphasis of the discussion. For example, the data force a stress on simple origin-destination analysis rather than characteristics which are common to geographically distinct migrations. The pervasive use of the Java-Outer Islands dichotomy can be criticized on the grounds that the Outer Islands seem to be taken as an entity contrasted with Java instead of as a residual category. 7 But the practical difficulty is that in sample surveys a considerably larger sampling fraction would have to be used outside

4. Widjojo Nitisastro, "Migration, Population Growth and Economic Development in Indonesia" (diss., University of California, Berkeley, 1961). This work also includes the most complete critical evaluation yet made of pre-1961 demographic materials.

5. C. E. Cunningham, The Postwar Migration of the Toba-Bataks to East Sumatra (New Haven: Yale University, Southeast Asia Studies, 1958).

6. Jacob Vredenbregt, "Bawean Migrations," Bijdragen tot de TaalLand- en Volkenkunde (CXX, 1), 1964, pp. 109-139.

7. A similar objection can be made to urban-rural analysis where the term "rural" is defined as non-urban. For a discussion of this problem see the introduction by Ruth Glass to UrbanRural Differences in Southern Asia: Report on Regional Seminar Delhi, 1962 (Delhi: UNESCO Research Centre on Social and Economic Development in Southern Asia, 1964). 
Java to enable even moderately accurate discrimination between disparate ethnic or regional groups. In practice, cost considerations weight the designing of surveys in favor of Java because of the high transport costs elsewhere.

\section{The Data}

Several categories of available statistical data are relevant to migration, the most pertinent being the results of the second round of the National Sample Survey, 8 a countrywide household survey with a sampling fraction of one thousandth, held in January 1965. The questions asked in this investigation covered length of residence in present desa ${ }^{9}$ or town (excluding short visits to other places) and, for those of less than five years' residence, the last place of dwelling and main reason for moving. The tables provided include information on the age, sex, marital status, and education of migrants. Some doubt has been cast on the reliability of this survey, as it was held at a time of considerable economic difficulty and political tension. The estimates of birth and death rates derived from it are clearly too low, but it is not clear whether this is a result of errors by the respondents or of faults in the design and coverage of the sample. Another source of data of this type, but far less detailed, is the Department of Labor's series of labor force sample surveys, which were made with ILO advice in 1957-59 and which provide information on mobility over a set reference period. The largest and most valuable of these covered the whole of Java; returns of a 1959 survey in South Sumatra were never processed.

8. The Survey Sosial Ekonomi Nasional (abbreviated NSS or Susenas) was carried out by the Statistical Research and Development Center of the Central Bureau of Statistics. Round two covered all Indonesia except East Nusatenggara, Maluku, and West Irian, but returns for Djakarta Raya were not processed due to serious faults in the coverage of that area.

9. Village complex; an administrative unit, several of which make up a ketjamatan (subdistrict). Outside Java, and between urban and rural areas in Java, there are large variations in the size of desa; the Indonesian average is about 2,500 persons, varying from 1,000 or less in West, Central, and East Kalimantan, North and South Sulawesi, and Maluku to over 4,000 in West Java, West Sumatra, and Djambi. Urban desa in most provinces are larger on the average than rural desa, exceeding 15,000 in Djakarta, West Java, and Riau. See Daftar Banjaknja Lingkungan Disusun Ketika Sensus Penduduk Th. 1961 (Djakarta: Biro Pusat Statistik, 1964)., assuming 500 persons per enumeration district. 
A second broad category of data indicating migratory trends comes from the Demographic Survey, a longitudinal follow-up survey primarily designed to estimate vital rates. To date four rounds have been held, in December 1962, January 1964, February 1965, and April 1967. Each enumeration district of about 500 people sampled in the survey which followed the 1961 census was revisited on these occasions, and changes in household occupants were recorded. Unfortunately, no distinction was drawn in the tabulations between movement within the same kotapradja (municipality) 10 or kabupaten (regency) and movement between widely spaced regions. This does not bias figures of net in- or outmigration, but it certainly raises their incidence of error. More seriously, it is also very likely that while outmigration is fairly completely covered, inmigration is under-recorded.

The only highly reliable category of information is the census data on place of birth. The 1930 census determined birthplace by kawedanaan (district) and was tabulated by residency, but in the 1961 census classification was only by province. In the latter, especially, it is difficult to determine the urban or rural origins of migrants. Again, the figures obscure temporal changes in rates and even directions of flow if they are used as an index of migration, as they include the violent demographic consequences of the war and revolution. An oblique picture of post-Independence trends can, however, be elicited from comparisons of age-specific census birthplace data with age distributions at previous times. No cross-classifications of birthplace by other characteristics were tabulated. 11

The tables of population by ethnic group given in the 1930 census provide the only general source of information on these groups' differing propensities to migrate although this is one of the more interesting aspects of Indonesian internal migration. It is most unlikely that future official statistics will cover this characteristic. In areas where a single ethnic group makes up almost the entire population, birthplace data can of

10. I have retained the term in this essay because it is more familiar than the official word (for all municipalities except Djakarta Raya), kotamadya. For the same reason, I refer to "province" instead of "first level autonomous region."

11. Due to delays in processing, data from the 1961 census on urban areas of West Java and Outer Island provinces are not available except in a one percent sample, and for rural areas there is no specification by age. At present the data are a mixture of preliminary figures (as published in the reports S.P.I and S.P.II) and revised final figures (for Java except West Java and parts of Central Java). 
course be substituted, but this may still blur important distinctions. 12

Finally, some corroborative data on aspects of migration are provided in information collected by the Transmigration Service and the Department of Labor (on organized outmigration from Java) and by local government agencies. However, the latter are useful only as a qualitative guide except in those few areas, such as the Special Territory of Jogjakarta, which possess developed statistical systems.

From the above outline it can be seen that little detailed information exists on many of the most important aspects of migration. The selective factors that produce migration are perhaps best approached by studying the characteristics of migrants--their family structure, education, occupation before and after moving, and so on--and their expressed reasons for moving. The 1964/65 National Sample Survey goes some way towards adducing data on these topics, but the small size of the sample does not permit a detailed tabulation of the results.

\section{Stability of Population}

As other countries which have agricultural economies and are not experiencing rapid economic development, Indonesia has a highly immobile population. This is illustrated, for example, in the labor force sample surveys summarized below (Table I). In all the rural areas surveyed, over 98 percent of the population had been living in the same desa twelve months previously. The survey in Wurjantoro, a deficient limestone region in rural Central Java, indicated that 96 percent of its 1957 population had been living in the same desa in 1950. These results are not unexpected, as there are few incentives favoring migration into rural Java, while the traditional social structure inhibits movements between desa. A household survey held in the Special Territory of Jogjakarta in 1958-1959 indicated that over 80 percent of heads of families living outside the city boundaries had been born in the same desa in which they were living--88 percent for Sleman and Kulon Progo kabupaten--and about 93 percent in the same kapanewon (ketjamatan). 13 of course this does not take into account outmigration from rural areas, both to the cities and to the Outer Islands. The only survey of an area outside

12. For a discussion of this problem as it affects estimates of Chinese migration to Djakarta, see Castles, 으. cit., pp. 172-177.

13. Suratman Wirjosudarmo (ed.), Beberapa Penemuan Pokok Penjelidikan Anggaran Belandja Keluarga di Daerah Istimewa Jogjakarta (Jogjakarta: Universitas Gadjah Mada, 1964), Table 5. 


\begin{tabular}{|c|c|c|c|c|c|c|c|}
\hline \multirow[b]{3}{*}{$\begin{array}{c}\text { Year } \\
\text { of } \\
\text { survey }\end{array}$} & \multirow[b]{3}{*}{$\begin{array}{l}\text { Province and } \\
\text { survey region }\end{array}$} & \multirow[b]{3}{*}{$\begin{array}{l}\text { Sampling } \\
\text { fraction }\end{array}$} & \multirow[b]{3}{*}{$\begin{array}{l}\text { Refer- } \\
\text { ence } \\
\text { period } \\
\text { (months) }\end{array}$} & \multicolumn{4}{|c|}{$\begin{array}{l}\text { Distribution of population of survey } \\
\text { region by place of residence at } \\
\text { start of reference period }(\%)\end{array}$} \\
\hline & & & & \multirow[b]{2}{*}{$\begin{array}{l}\text { Same } \\
\text { desa }\end{array}$} & \multicolumn{2}{|c|}{ Different desa } & \multirow[b]{2}{*}{ Total } \\
\hline & & & & & $\begin{array}{l}\text { Same } 2 \text { nd } \\
\text { order } \\
\text { regiona }\end{array}$ & $\begin{array}{l}\text { Different } \\
\text { 2nd order } \\
\text { region }\end{array}$ & \\
\hline & West Java & & & & & & \\
\hline 1957 & $\begin{array}{l}\text { Kotapradja } \\
\text { Sukabumi }\end{array}$ & 0.012 & 12 & 89.6 & 8.1 & 2.3 & 100.0 \\
\hline 1957 & $\begin{array}{c}\text { Kabupaten } \\
\text { Sukabumi }\end{array}$ & 0.003 & 12 & 99.6 & 0.3 & 0.1 & 100.0 \\
\hline \multirow[t]{2}{*}{1957} & $\begin{array}{l}\text { Kotapradja } \\
\text { Bandung }\end{array}$ & 0.003 & 12 & 96.2 & 2.1 & 1.7 & 100.0 \\
\hline & Central Java & & & & & & \\
\hline \multirow[t]{2}{*}{1957} & $\begin{array}{l}\text { Kawedanaan } \\
\text { Wurjantoro }\end{array}$ & 0.01 & $\begin{array}{l}92 \\
32\end{array}$ & $\begin{array}{l}96.2 \\
98.0\end{array}$ & $\begin{array}{l}3.2 \\
1.3\end{array}$ & $\begin{array}{l}0.6 \\
0.7\end{array}$ & $\begin{array}{l}100.0 \\
100.0\end{array}$ \\
\hline & North Sulawesi & & & & & & \\
\hline 1957 & $\begin{array}{l}\text { Kabupaten } \\
\text { Minahasa }\end{array}$ & 0.003 & $\begin{array}{l}92 \\
32\end{array}$ & $\begin{array}{l}95.0 \\
99.3\end{array}$ & $\begin{array}{l}2.3 \\
0.4\end{array}$ & $\begin{array}{l}2.7 \\
0.3\end{array}$ & $\begin{array}{l}100.0 \\
100.0\end{array}$ \\
\hline \multirow[t]{3}{*}{1958} & Java & & & & & & \\
\hline & urban areas ${ }^{\mathrm{b}}$ & 0.001 & 12 & 96.5 & 1.9 & 1.6 & 100.0 \\
\hline & rural areas & 0.001 & 12 & 98.7 & 0.7 & 0.6 & 100.0 \\
\hline
\end{tabular}

a. Kabupaten or kotapradja.

b. Comprising the 18 kotapradja with (1958) populations of over 50,000 .

Source: Compiled from the various LFSS reports published by the Department of Labor and the unpublished report on Minahasa. 
Java, that of Minahasa kabupaten in North Sulawesi, shows a higher proportion of inmigrants from a different second level region. 14 In the urban 25 areas of Java only 3.5 per cent of the 1958 population had moved into the desa of enumeration over the previous year, and less than half this fraction (approxi-

Table 2. Mobility of Population, 1964

\begin{tabular}{|c|c|c|c|c|c|c|c|}
\hline \multirow[b]{3}{*}{ Region } & & \multicolumn{6}{|c|}{ Percentage of } \\
\hline & & \multicolumn{5}{|c|}{ Less than } & \multirow{2}{*}{$\begin{array}{c}\text { More } \\
\text { than } 5 \\
\text { years }\end{array}$} \\
\hline & & 1 year & 2 yrs & 3 yrs & 4 yrs & $5 \mathrm{yrs}$ & \\
\hline Java ${ }^{a}$ & $\begin{array}{l}\text { urban } \\
\text { rural } \\
\text { total }\end{array}$ & $\begin{array}{l}3.0 \\
1.2 \\
1.4\end{array}$ & $\begin{array}{l}6.0 \\
2.4 \\
2.8\end{array}$ & $\begin{array}{l}8.6 \\
3.2 \\
3.8\end{array}$ & $\begin{array}{r}10.6 \\
3.8 \\
4.6\end{array}$ & $\begin{array}{r}12.1 \\
4.5 \\
5.3\end{array}$ & $\begin{array}{l}87.9 \\
95.5 \\
94.7\end{array}$ \\
\hline $\begin{array}{l}\text { Outer } \\
\text { Islands }\end{array}$ & $\begin{array}{l}\text { urban } \\
\text { rural } \\
\text { total }\end{array}$ & $\begin{array}{l}2.2 \\
1.7 \\
1.8\end{array}$ & $\begin{array}{l}4.6 \\
2.9 \\
3.1\end{array}$ & $\begin{array}{l}6.6 \\
3.9 \\
4.3\end{array}$ & $\begin{array}{l}8.8 \\
4.7 \\
5.2\end{array}$ & $\begin{array}{r}10.1 \\
5.4 \\
6.0\end{array}$ & $\begin{array}{l}89.9 \\
94.6 \\
94.0\end{array}$ \\
\hline
\end{tabular}

b. Excluding East Nusatenggara, Maluku and West Irian.

Source: Based on National Sample Survey, 1964/65.

14. Migrants were mostly from Sangihe Talaud and Bolaang Mongondow kabupaten. See J. N. Bhatta, Tindjauan tentang, Kediaman Orang jang Beragama Islam di Minahasa (Djakarta: Direktorat Topografi Angkatan Darat, 1958), p. 18.

15. For the all-Java LFSS, urban areas were defined as the 18 kotapradjas with populations of over 50,000; rural areas were the residual. In the 1961 census urban areas were defined as kotapradja, kabupaten capitals, and certain other towns "with urban characteristics" as judged by census and local government officials and with a population of more than 20,000. Kotapradja were administratively delimited; all other urban areas consisted in each case of several adjoining desa, the number being determined by census officials in conjunction with the local authorities. (The wide differences in the concept of "desa" in different regions, especially outside Java, has been noted earlier; clearly they affect the comparability of urban areas in different provinces.) There was no lower limit on population for kabupaten capitals, although some were excluded on other grounds. Rural areas were again defined residually. This definition was retained with only slight modifications in the Demographic Survey and the National Sample Survey. 
mately 130,000 persons) had come from another second level re-
gion. 16

A broader picture is given by the National Sample Survey. Respondents in rural areas who had lived in their present desa for less than five years, except for short visits to other places, were classified by year of moving, and so were those in urban areas who had moved into their present town less than five years previously (see Table 2 on previous page). Again, the stability of the whole population is notable. Rural areas of Java were shown to contain a smaller proportion of inmigrants than rural areas of the Outer Islands, while for urban areas the positions are reversed. (In 1964, inmigrants to rural areas of Java totalled 1.2 percent of the rural population, consistent with the equivalent figure of 1.3 percent for 1958 from the labor force survey of that year.)

Population movements over 1960-1964 are broken down in Table 3 to show the relative importance of inter- and intraisland migration. Internal migration in Java makes up about 60 per cent of all recorded movements in Indonesia, but, as further analysis shows, less than one-tenth of this percentage is interprovincial migration. Relative to total population, internal migration in the Outer Islands is of equal significance. Migration from Java to the Outer Islands is larger both absolutely and relatively than the opposite movement (excluding inmigration to Djakarta), but when the urban or rural nature of the destination is considered we can see that three-quarters of the former flow is directed to rural areas of the Outer Islands, while more than half of the inmigrants to Java go to urban areas. This fact will be examined in more detail below. Specification of the data in Table 3 by sex revealed no features of interest apart from the fact that a higher proportion of males went to Java than departed from it.

The National Sample Survey also allows us to make tentative statement on the permanence of migration. In Table 2 the increments in each column become successively smaller as some of the inmigrants die, move on, or return to their former homes. (This interpretation necessarily assumes that there was no significant change in migratory patterns over the reference period 19601964.) The estimated numbers of the different categories of migrants for each of the five years are given in Table 4. They show considerable random fluctuation, but there is some reason to conclude that only about one in three persons who migrate between Java and the outer Islands stays at his destination longer than a few years, whereas intra-island migrants are more

16. The unusually high mobility within Sukabumi kotapradja is suspect; this survey, the first to be held, was a pilot survey. 
likely to remain for a long term.

Table 3. Percentage Distribution of Population Movements a by Category of Movement and Urban or Rural Destination, 1960-1964

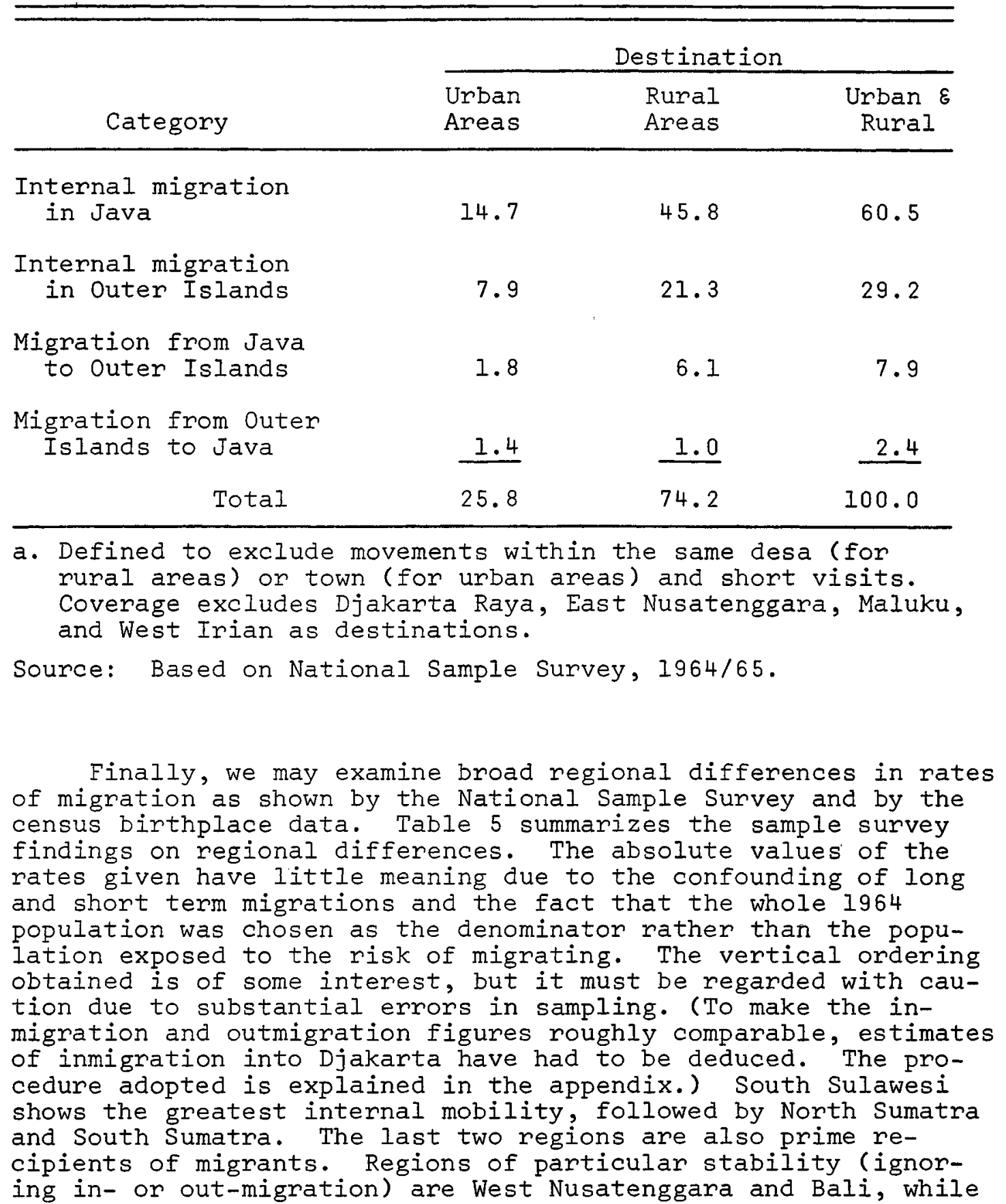


Table 4. Number of Recent Internal Migrants Enumerated in 1964 by Category and Year of Migration (in thousands)a

\begin{tabular}{|c|c|c|c|c|c|c|c|}
\hline \multirow[b]{2}{*}{ Category } & \multirow{2}{*}{$\begin{array}{l}\text { Urban/rural } \\
\text { destination }\end{array}$} & \multicolumn{5}{|c|}{ Year of Migration } & \multirow{2}{*}{$\begin{array}{r}\text { Total } \\
1960-4\end{array}$} \\
\hline & & 1964 & 1963 & 1962 & 1961 & 1960 & \\
\hline $\begin{array}{l}\text { Internal migrants } \\
\text { in Java. }\end{array}$ & $\begin{array}{l}\text { urban } \\
\text { rural }\end{array}$ & $\begin{array}{l}188 \\
651\end{array}$ & $\begin{array}{l}191 \\
630\end{array}$ & $\begin{array}{l}171 \\
465\end{array}$ & $\begin{array}{l}126 \\
353\end{array}$ & $\begin{array}{l}101 \\
320\end{array}$ & $\begin{array}{r}777 \\
2419\end{array}$ \\
\hline $\begin{array}{l}\text { Internal migrants } \\
\text { in Outer Islands }\end{array}$ & $\begin{array}{l}\text { urban } \\
\text { rural }\end{array}$ & $\begin{array}{r}93 \\
336\end{array}$ & $\begin{array}{l}103 \\
257\end{array}$ & $\begin{array}{r}85 \\
209\end{array}$ & $\begin{array}{r}91 \\
276\end{array}$ & $\begin{array}{r}46 \\
138\end{array}$ & $\begin{array}{r}418 \\
1216\end{array}$ \\
\hline $\begin{array}{l}\text { Migrants from Java } \\
\text { to Outer Islands }\end{array}$ & $\begin{array}{c}\text { urban \& } \\
\text { rural }\end{array}$ & 152 & 94 & 82 & 59 & 32 & 419 \\
\hline $\begin{array}{l}\text { Migrants from Outer } \\
\text { Islands to Java }\end{array}$ & $\begin{array}{c}\text { urban } \varepsilon \\
\text { rural }\end{array}$ & 36 & 49 & 12 & 19 & 14 & 130 \\
\hline
\end{tabular}

a. Excluding migrants to on within Djakarta Raya, East Nusatenggara, Maluku, and West Irian.

Source: Based on National Sample Survey, 1964/65. 
Central Sumatra is important as a region of outmigration only. The proportions of outmigrants from West and Central Java are comparatively large, due mainly to urban migration to Djakarta.

Table 5. Interregional and Intraregional Movements as a Proportion of 1964 Regional Population, 1960-1964 (numbers in thousands)

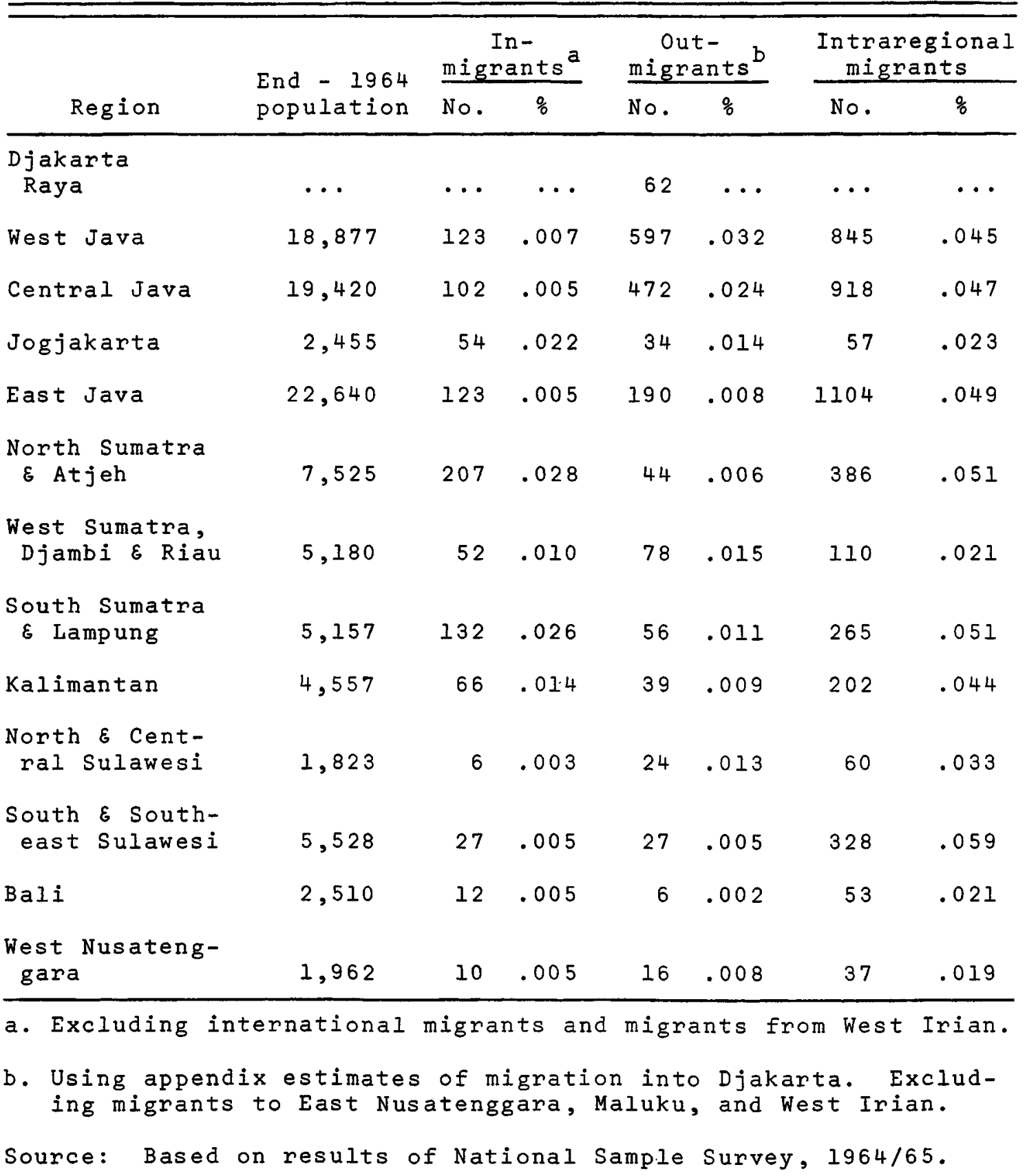


The census data give an indication of total inmigration but not necessarily of recent patterns; thein usefulness lies mainIy in their accuracy and degree of detail. However, because of the persistence of many migratory movements--or rather the persistence of the factors giving rise to them--the 1930 and 1961 statistics do not differ radically. The 1930 census recorded that $3,336,575$ persons, or 5.64 percent of the Indonesian population, had moved to a different district or subdivision

(onderafdeeling) in their residency of birth, and that $3,332,508$ ( 5.63 percent) had moved to a different residency. In Java, 91 percent of the rural population had been born in the same district and 99 percent in the same residency. In urban areas (i.e., cities and towns "of urban appearance" and with a population of not less than 1,000), the corresponding percentages were 66 and 92. Outside Java there were appreciably more inmigrants to both rural and urban areas, particularly to the latter: only 60 percent of the town population had been born in the same district. 17 The pattern is broadly consistent with the recent sample survey indication of the stability of the rural population; still better, it can be compared with the 1961 birthplace data given in Table 6 . In 1961 rural sumatra, Kalimantan, and Maluku contained the langest outborn populations. In Sumatra and Kalimantan the inmigrants were mainly from Java, while in Maluku (as will be shown later) the majority were from sulawesi. Of the four major islands, Kalimantan recorded the greatest degree of migration across provincial land boundaries, but as this involved little more than 2 percent of the enumerated population it is hardly of great significance. At the other extreme, the rural areas showing fewest inmigrants relative to their populations and least internal mobility were in the provinces of Java, particularly East and Central Java, and Nusatenggara and Sulawesi. When smaller geographical areas are examined these regional differences appear in higher relief.

\section{NONSECULAR MIGRATIONS}

There is no precise distinction between long-term persistent migratory flows and the infrequent large movements of people that can inundate one region and significantly depopulate another within a relatively short period of time. The latter, which I shall call nonsecular migrations, have usually followed longestablished routes; this is understandable, as they have been stimulated largely by conditions in the sending region--most commonly insecurity in rural areas during religious or separatist

17. Volkstelling 1930 (VIII), PP. 19, 47. Two sources of error mentioned by the census supervisors were the tendency of people to return to their places of birth to be enumerated, and a bias in favor of districts of birth with the same names as the regencies containing them.

Source for Table 6: Computed from 1961 census data (final figures for provincial totals in Java; 90 percent sample for all rural areas; urban areas obtained as residuals). 
Table 6. Percentage Distribution of Population of Major Regions by Location of Province of Birth Relative to Province of Enumeration, 1961

\begin{tabular}{|c|c|c|c|c|c|c|c|c|}
\hline \multirow[b]{2}{*}{$\begin{array}{l}\text { Region of } \\
\text { enumeration }\end{array}$} & & \multicolumn{6}{|c|}{ Place of Birth } & \multirow[b]{2}{*}{ Total } \\
\hline & & $\begin{array}{c}\text { Same } \\
\text { province }\end{array}$ & $\begin{array}{l}\text { Contiguous } \\
\text { province }\end{array}$ & $\begin{array}{l}\text { Elsewhere } \\
\text { in Java }\end{array}$ & $\begin{array}{l}\text { Outer } \\
\text { Islands }\end{array}$ & $\begin{array}{l}\text { Over- } \\
\text { seas }\end{array}$ & $\underset{\text { known }}{\text { Un- }}$ & \\
\hline Djakarta Rayab & & 51.0 & 26.9 & 14.1 & 6.7 & 1.1 & 1.2 & 100.0 \\
\hline West Java & $\begin{array}{l}\text { urban } \\
\text { rural } \\
\text { total }\end{array}$ & $\begin{array}{c}9 \ddot{8} .8 \\
\ldots\end{array}$ & $\begin{array}{l}\ddot{0} .9 \\
. .\end{array}$ & 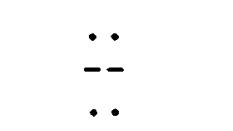 & $\ddot{0.1}$ & $\ddot{-}$ & $\begin{array}{l}\ddot{0} .2 \\
. .\end{array}$ & $\begin{array}{l}100.0 \\
100.0 \\
100.0\end{array}$ \\
\hline Central Javac & $\begin{array}{l}\text { urban } \\
\text { rural } \\
\text { total }\end{array}$ & $\begin{array}{l}89.5 \\
99.1 \\
98.4\end{array}$ & $\begin{array}{l}5.6 \\
0.5 \\
0.8\end{array}$ & $\begin{array}{l}0.3 \\
-- \\
--\end{array}$ & $\begin{array}{l}2.5 \\
0.1 \\
0.3\end{array}$ & $\begin{array}{l}0.7 \\
-0.1\end{array}$ & $\begin{array}{l}1.4 \\
0.3 \\
0.4\end{array}$ & $\begin{array}{l}100.0 \\
100.0 \\
100.0\end{array}$ \\
\hline D.I.Jogjakarta & $\begin{array}{l}\text { urban } \\
\text { rural } \\
\text { total }\end{array}$ & $\begin{array}{l}74.0 \\
98.3 \\
94.3\end{array}$ & $\begin{array}{r}14.2 \\
0.9 \\
3.0\end{array}$ & $\begin{array}{l}6.6 \\
0.2 \\
1.3\end{array}$ & $\begin{array}{l}3.9 \\
0.1 \\
0.7\end{array}$ & $\begin{array}{l}0.4 \\
-0.1\end{array}$ & $\begin{array}{l}0.9 \\
0.5 \\
0.6\end{array}$ & $\begin{array}{l}100.0 \\
100.0 \\
100.0\end{array}$ \\
\hline East Java & $\begin{array}{l}\text { urban } \\
\text { rural } \\
\text { total }\end{array}$ & $\begin{array}{l}90.1 \\
99.3 \\
97.9\end{array}$ & $\begin{array}{l}3.2 \\
0.5 \\
0.9\end{array}$ & 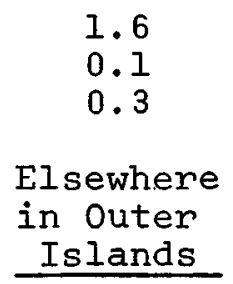 & $\begin{array}{l}2.5 \\
0.1 \\
0.4\end{array}$ & $\begin{array}{l}1.0 \\
-- \\
0.2\end{array}$ & $\begin{array}{l}1.6 \\
0.2 \\
0.3\end{array}$ & $\begin{array}{l}100.0 \\
100.0 \\
100.0\end{array}$ \\
\hline Sumatra & rural & 87.7 & 1.1 & 0.7 & 9.5 & 0.4 & 0.6 & 100.0 \\
\hline Kalimantan & rural & 94.6 & 2.1 & 1.0 & 1.8 & 0.2 & 0.3 & 100.0 \\
\hline Sulawesi & rural & 98.5 & $0.5^{\circ}$ & 0.1 & 0.4 & -- & 0.5 & 100.0 \\
\hline Nusatenggara & rural & 99.2 & -- & 0.3 & 0.2 & 0.1 & 0.2 & 100.0 \\
\hline Maluku & rural & 95.7 & -- & 3.0 & 0.6 & 0.2 & 0.5 & 100.0 \\
\hline
\end{tabular}

\section{a. Sharing common land border.}

b. The breakdown between people born in Djakarta Raya and West Java may not be strictly accurate due to errors in recording the place of birth relative to the post-1950 boundaries.

c. Excluding urban areas other than kotapradja. 
revolts. The major case in which such a stimulus was not the most important factor was the great outmovement of Bataks from North Tapanuli to the East Coast of Sumatra in the years immediately following the revolution.

\section{The Batak Migration 18}

The 1930 census enumerated 74,224 Toba Bataks in the East Coast residency of Sumatral9 ( 15 percent of the number in Batakland itself); 53,000 of these were in the afdeeling of Simalungun and Karo on the northern and eastern sides of Lake Toba and another 18,000 were in Asahan. It is likely that the great majority were migrants from Tapanuli: there were nearly 60,000 Tapanuli-born residents of the East Coast. 20 Pressures of overpopulation had long existed in the Toba highlands, but the immediate reason for the movement was the government's extension of irrigation facilities in Simalungun and Asahan and its policy of encouraging skilled wet rice cultivators to replace swidden farmers in these areas. Large scale migration was prevented both by the hostility of the East Coast sultans to the predominantly Christian Batak and by the fact that the greater part of the East Coast land was held in concessions by the estates. With the war and revolution the longstanding restrictions on squatting were no longer enforceable, and in the period 1941-1950 an estimated half million people occupied land in the East Coast, much of it on estate concessions. ${ }^{1}$ The early squatters were mostly Javanese estate workers and local Karo Batak and coastal Malay. But especially after the end of the revolution in 1949 they were joined by Toba Batak migrants from North Tapanuli. The historical push effect of overpopulation combined with the attraction of the more fertile East Coast land, irrigation, and better services (in particular transport facilities, which provided easier access in markets). Not only were there no effective legal barriers to the occupation of land, but the squatters considered that they were moraliy entitled to claim their "hadiah revolusi," the reward for their achievement of independence. Cunningham estimates that at least 250,000 Toba Batak migrated to the East Coast in the period 1950-

18. For a full discussion of this subject, with an anthropological emphasis, see Cunningham, op. cit.

19. This comprised the present province of North Sumatra, excluding the four kabupaten of the former Tapanuli residency, and Bengkalis kabupaten of the present province of Riau.

20. Volkstelling 1930 (IV), PP. 162-163; (VIII), p. 94.

21. Cunningham, op. Cit., P. 89. 
1956.22 A different source puts the total number of outmigrants from the three Tapanuli kabupaten (excluding Nias) by 1960 at 125 percent of the then population of Tapanuli itself (which in 1961 exceeded one miliion); most of them went to East Sumatra. 23 As this figure also covers outmigration of Muslim Batak from South Tapanuli and can be assumed to include natural increase after migration, it is broadly consistent in order of magnitude with Cunningham's estimate.

Because almost the whole of this population movement is within the province of North Sumatra it does not clearly show up either in the census of 1961 or in the National Sample Survey. Cunningham plotted its course from the expansion of the Batak Protestant Church, which followed the path of the migrants. The one minor route that did cross a provincial border was the movement along the road joining Karo and Atjeh Tengah. The census records about 14,000 North Sumatra-born residents of Central Atjeh (outside its capital Takengon); most of these were probably Toba Batak, as already in 1930 there was a Tapanuli-born population in Atjeh of over 5,000, though the entire Batak population of that area hardly exceeded 7,000 . Smaller numbers of North Sumatrans are found in the two adjacent kabupaten, South Atjeh and East Atjeh. A quantitative indication of inmigration to the East Coast will be possible from an analysis of the 1961 census birthplace data, after excluding the very considerable number of inmigrants from other provinces, notably Central Java; but this data is not presently available.

\section{Regional Rebellions: the Darul Islam Movement}

The various rebellions which Indonesia experienced after the transfer of sovereignty from the Dutch fall broadly into three categories. Firstly there were those involving members of the former Royal Netherlands Indies Army (KNIL), which was dissolved under the terms of the Round Table Agreement of 1949; the short-lived revolts of Westerling in West Java, Andi Azis in South Sulawesi, and the rebellion of the "Republic of South Maluku" (RMS). These all took place in 1950, and only the RMS affair lasted more than a few months. 24 Far more significant

22. Ibid., p. vii.

23. Office of the Governor of North Sumatra, Medan, quoted in Monografi daerah: Daswati II Tapanuli (Djakarta: Biro Industrialisasi/Fakultas Ekonomi U.I., 1962).

24. A short military campaign against the RMS involving landings by government troops on Ambon, Buru, and Ceram islands and the Tanimbar and Kai groups was followed by some years of guerrilla activities, mainly on Ceram. See Sedjarah Singkat Perdjuangan Bersendjata Bangsa Indonesia ([n.p.]: Staf Angkatan Bersendjata, 1964), PP. 94-97. 
44

were the series of Islamic rebellions: Kartosuwirjo's Darul Islam (State of Islam) movement in West Java (1948-1962) and three others loosely connected with it--Kahar Muzakar's revolt in South/Southeast Sulawesi25 (1951-1965), Daud Beureuh's rebellion in Atjeh (1953-1957 and 1959-1961) and Ibnu Hadjar, a much less effective movement in South Kalimantan, which operated intermittently between 1950 and the early 1960's. The third category comprises the affair of the Revolutionary Government of the Republic of Indonesia (PRRI), set up in Padang in early 1958, and the associated Permesta rebellion in North/Central Sulawesi. These movements were unlike the others in that they involved many elite politicians and claimed greater political and financial autonomy for the Outer Islands from Djakarta in particular and Java in general. It would be natural to assume that the demographic consequences of the Darul Islam movement differed in important respects from those of the PRRI. However, the statistical evidence is inconclusive on this point, and we have to rely mainly on the rough assessments of local officials and reports of the participants themselves.

Kartosuwirjo's Darul Islam rebels were active in various parts of West Java and in adjacent areas of Central Java from 1948 until the capture of their leader in mid-1962. Their campaign of terrorism and sabotage was directed primarily against the government, but in practice it was often indiscriminate. 26 The area and intensity of their operations varied considerably over this long period; the kabupaten of Tasikmalaja, Tjiamis, and Garut in the residency of Priangan and Brebes in Central Java were probably the worst affected, but parts of Bogor, Sukabumi, and Tjiandjur also experienced long periods of insecurity, and the north coast kabupaten from Krawang to Purwakarta were affected, if to a lesser extent. Economic opportunities inevitably shrank in rebel-threatened or rebel-controlled areas, as roads and railways became unsafe and as peasants limited their output of foodcrops in response to rebel requisitions. The number of villagers who fled their homes is difficult to gauge accurately. Figures from the office of the Governor of West Java put the total at 215,700 over the period 1951-1956, and at 52,672 in the last quarter of 1951 alone.27 According to Castles,

25. In 1964 Southeast Sulawesi (the former afdeeling of Butung and Laiwui) was made a separate first level region.

26. For a contemporary government account, see Republik Indonesia: Propinsi Djawa Barat (Djakarta: Kementerian Penerangan, 1954), pp. 212-253.

27. Ibid., p. 239, and Indonesian Observer, January 19, 1957. For the 1951-1956 period other Darul Islam victims were given as follows: 13,257 killed; 1,622 kidnapped; 4,832 wounded; and 266,952 whose houses were burnt or plundered. 
most refugees from central and eastern Priangan moved to the towns of Tasikmalaja and Bandung, both of which showed rapid growth between 1930 and 1961 (respectively 390 percent and 480 percent). 28 However if, as one account suggests, 29 the marginal existence that the refugees faced in the towns caused many to return to the insecure areas, then the intercensal urban growth would not give a very complete picture of the actual movements. It is not clear how many people migrated to Djakarta for security reasons. The 1953 urbanization survey showed only 2.1 percent of outborn male household heads in this category, with little difference between migrants from urban and rural areas; but it is possible that this figure is misleading. 30

Some indication of the seriousness of the urban refugee problem in the early 1950's is given by the efforts made at resettlement. From 1950 to 1954 the newly established Transmigration Service resettled in Banten a total of 1,299 families (5,032 people) who had fled to towns in the east Priangan region from rebel areas. Under the program, known as "local transmigration," it had initially been planned to move 5,000 refugee families to Banten in 1952 alone, and settlements had been established in Serang and Lebak kabupaten. As it happened, lack of funds forced a curtailment, and no further migrants were sponsored after 1954.31 On the other hand, there was evidently little urban migration in the final stages of the rebellion in West Java: of the 845,000 people who were estimated to have moved between desa or towns in West Java in the years 1960-1964, some 36,000 did so for reasons of security, but almost none of them went to urban areas as those have been defined. ${ }^{32}$

In South/Southeast Sulawesi the picture is rather less clear, as the effects of the Kahar Muzakar rebellion are

28. Castles, ㅇp. cit., p. 191 (growth rates computed by present writer).

29. Republik Indonesia: Propinsi Djawa Barat, p."239. The urban refugees are described as "terlantar."

30. Heeren, op. cit., p. 36. Castles (op. cit., p. 191) suggests that the result may be due to the choice of sample, which covered ketjamatan with known high proportions of inmignants but excluded fringe areas, where the West Java refugees may have concentrated. Another possibility is that villagers who initially fled to small towns may only later have sought the greater opportunities offered by the capital.

31. M. Amral Sjamsu, Dari kolonisasi ke transmigrasi 1905-1955 (Djakarta: Djambatan, 1960), p. 80f.

32. National Sample Survey, 1964/65. 
thoroughly confused with the historical outmigration tendencies of the Buginese and to a lesser extent the Makasarese. In 1930 the number of people born in South/Southeast Sulawesi who were living in other areas of Indonesia amounted to 2.13 percent of that region's enumerated population. The major settlement areas (apart from Malaya and British Borneo) were in East and South Kalimantan and in northern Sulawesi. The then residency of South/East Borneo contained 16,052 people born in southern Sulawesi (and more than three times as many ethnic Buginese and Makasarese), while the Sumatran residencies of the East Coast, Djambi, and Riau had less than 4,500 inhabitants from southern Sulawesi. ${ }^{33}$ Comparable data for 1961 are incomplete, but for rural areas alone the census showed over 42,000 persons born in South/Southeast Sulawesi living in Djambi and Riau provinces. 34 The major new settlement areas in 1961 were in the kabupaten of Batanghari (Djambi) and Indragiri and Kepulauan Riau (Riau). Poso (North/Central Sulawesi), Kutai (East Kalimantan), Kota Baru (South Kalimantan), Central Maluku, and Sumbawa, all with some history of inmigration from Sulawesi, showed minor increases in migrants compared to 1930.

The magnitude of the exodus from sulawesi resulting from the Kahar Muzakar rebellion is uncertain. One report quotes local government officials in Central sumatra as estimating that 10,000 of the (southern) Sulawesi-born population in Djambi and Riau in 1956 were refugees, ${ }^{35}$ while another mentions some 5,000 fishermen from sulawesi moving to the coastal areas and rivers of East Kalimantan in 1956.36 However, such figures are at best impressionistic. Some indirect evidence based on age distributions of Sulawesi-born migrants in Djakarta, to be discussed later in reference to urbanization, suggests that migration to Java from southern Sulawesi may have increased in the $1950^{\circ} \mathrm{s}$ by more than the average for Outer Island provinces and may have included a higher proportion of family migrants with young children. The National sample survey results, which, surprisingly,

33. Volkstelling 1930 (VIII), PP. 94-95. Riau excludes the kabupaten Bengkalis of the present province.

34. 1961 census; unpublished tables of 90 percent sample of rural areas (hereafter referred to as 90 percent sample). Where the inflating factor has not been determined the factor 1.111 is used and the results rounded at least to the nearest 100 .

35. Monografi daerah: Daswati I Djambi (Djakarta: Biro Industrialisasi/Fakultas Ekonomi U. I., 1962).

36. Hasil2 questionnaire Rentjana Pembangunan Daerah dari Daerah Kalimantan Timur (Djakarta: Biro Perantjang Negara/ Fakultas Ekonomi U. I., 1958). 
show a small net inmigration over the period 1960-1964 into South/Southeast Sulawesi, presumably from Djambi and Riau, (see Figure 1), could possibly be interpreted as a blackflow of refugees taking place as areas of security were extended; but in view of the sampling errors involved, the size of these migratory flows must be regarded with caution.

Within the province of South/Southeast Sulawesi, the effects of the rebellion seem to be reflected in the rapid growth of various towns. Between 1930 and 1961 the kotapradja of Makasar and Parepare and the kabupaten capitals Watampone and Baubau had average annual growth rates of respectively $4.9,7.7$, 8.3 and 6.9 percent. 37 Each of these towns was close to rebelcontrolled country in 1961. Indeed the state of insecurity in 1961 is well indicated by the number of areas which could not be enumerated in the population census. Only two kabupaten, Madjene and Polewali-Mamasa, could be completely covered. In Luwu, Mamudju, Enrekang, Wadjo, and Barru less than half the estimated rural population was surveyed, and the kabupaten of Bone, Kendari, and Muna were also heavily underenumerated. These areas mostly lie on the northern and western sides of the Gulf of Bone and in the Lasolo River region of Southeast Sulawesi, where Kahar Muzakar was eventually killed in 1965.

The rebellion in Atjeh began in 1953 with attacks on all the major towns. A number of them, including Takengon, capital of Central Atjeh, were occupied by the rebels for short periods, but all were retaken by government forces before the end of the year. ${ }^{38}$ Subsequent guerrilla activities lasted until 1961. The areas involved, on the evidence of the stationing of garrison troops, were Atjeh Besar and Pidie, parts of the west coast (Meulaboh and Tapaktuan) and the Gajo mountains of Central Atjeh. ${ }^{39}$ The important estate region of East Atjeh was also affected. Many people moved across the residency border 40 into the northernmost East Coast kabupaten of Langkat and Deli Serdang--one source puts the number of these refugees at 60,000.41 However,

37. Pauline D. Milone, Urban areas in Indonesia: Administrative and Census Concepts (Berkeley: University of California, 1966), P. 155 .

38. Ariwiadi, Gerakan Operasi Militer VII: penjelesaian Peristiwa Atjeh ([n.p.]: Mega Bookstore, 1965), pp. 3-10.

39. Ibid., p. 10 .

40. Atjeh became a separate province in 1956.

41. Hasil2 questionnaire Rentjana Pembangunan Daerah dari daerah Atjeh (Djakarta: Biro Perantjang Negara/Fakultas Ekonomi U. I., 1958). 
it is thought that most of them returned with the temporary restoration of security in 1957. The 1961 census showed an Atjeh-born population in rural areas of North Sumatra of some 14,700, mostly concentrated in Langkat and Deli Serdang; 42 in 1930 there had been only 6,559 Atjeh-born in the entire East Coast residency. As in West Java and southern Sulawesi, the Muslim rebellion probably accounted for the high growth rates of towns in Atjeh. Takengon and the capitals of East Atjeh and North Atjeh (respectively Langsa and Lhokseumawe) all had annual growth rates exceeding 5 percent between 1930 and 1961 , 43 while the 1961 sex ratio of 1280 for the provincial capital (Banda Atjeh) may indicate rapid urbanization.

In the last of the regions experiencing insecurity due to a Darul Islam-type movement, South Kalimantan, the effect seems also to have been increased urban migration, in this case from the mountainous country in Hulusungai to the only substantial urban center, Bandjarmasin. 44 It is not possible to estimate the proportion of refugees among the large numbers of outmigrants from this province, but the 1964/65 National Sample Survey (which did not subdivide Kalimantan) indicates a particularly large rise in intervillage movements in 1961 compared to the previous year, which may be attributable to the Ibnu Hadjar rebellion.

\section{The PRRI - Permesta Rebellion}

The PRRI rebel government was established in Central Sumatra in February 1958 at the end of a lengthy period in which important provinces outside Java were in the hands of regional councils which defied the authority of Djakarta. Outside Central Sumatra the PRRI received its strongest support from Tapanuli and North/Central Sulawesi (where the rebel movement was called Permesta). Central government troops rapidly gained control of the major rebel-held towns, but guerrilla fighting continued until most of the remaining insurgents were persuaded to surrender in 1961. Some movement of villagers out of the areas of

42. 1961 census, 90 percent sample.

43. Milone, op. cit., p. 155. It is notable that of the 14 towns showing 1930-1961 growth rates greater than 4.6 percent per year (i.e., over twice the recent growth rate of the whole population) 11 are situated in West Java, Atjeh and South/Southeast Sulawesi. Of the remaining three, in Riau and Djambi, two were probably swelled with migrants from southern Sulawesi.

44. Mongrafi daerah: Daswati I Kalimantan Selatan (Djakarta: Biro Industrialisasi/Fakultas Ekonomi U. I., 1963), p. 7 . 
actual guerrilla activity was recorded: in Tapanuli, for example, local registration statistics show a great rise (24 percent) in the population of the coastal town of Sibolga in 1958-1959 followed by a slight decline in the two following years. 45 Perhaps of more significance in the longer term, however, were the demographic effects occurring after the restoration of central control, during the subsequent "occupation" by government troops. Outmigration from North Sulawesi was evidently on quite a large scale, both from urban and rural areas. 46 Various factors may explain this: a lack of opportunities under a command-minded and unsympathetic military regime with poorly paid and often predatory soldiers; the deterioration of infrastructure, especially transport, and educational facilities as a result of unwillingness by the central government to reinvest in disaffected areas; in some instances expropriation of land or other property by the military or by persons with military backing; and, for those actually involved, active discrimination by the authorities. For people in this last category one attractive choice was to seek the anonymity offered by the large cities of Java--Djakarta, Surabaja, and Bandung. In West Sumatra, any substantial outmigration due to the rebellion is obscured by the Minangkabau tradition of leaving their homeland; movement to Java also took place there but it is difficult to quantify.

From these short accounts of the regional rebellions some qualitative differences in their demographic effects seem to be suggested. In the case of the Darul Islam campaigns, grass-roots movements 47 which proved extremely difficult to eradicate, the usual effects of terrorist activity were evident: movement of families from insecure rural areas to the larger towns, with a tendency for the reverse movement to take place as soon as security was restored. The migrants may be assumed representative of the rural population in age and family structure, level of education, and so on. In contrast, the PRRI-Permesta rebellion, which drew more support from the educated sections of the population, probably had less impact on the rural population, particularly in West Sumatra, where by many accounts the fighting was less severe. Although no figures can be given, the movement of educated persons to Java which followed the end of the fighting must have represented a serious drain of talent from the

45. Monografi daerah: Daswati2 II Tapanuli, p. 8.

46. According to one informant, the authorities in Minahasa, alarmed by the extent of outmigration in 1960-1961, tried to reduce the flow drastically by forbidding many categories of people from leaving at all.

47. An early official writer on the Kahar Muzakar rebels noted that "mereka berakar pada rakjat." Republik Indonesia: Propinsi Sulawesi (Djakarta: Kementerian Penerangan, 1954), p. 338 . 
regions, while at the same time increasing the potential role that Outer Island-born migrants could play in Java.

\section{Other Nonsecular Migrations}

The other substantial but unsustained population movements which have occurred since 1950 are those involving the Chinese and European minorities. In the latter case the movement was simply the mass emigration of Dutch nationals, averaging nearly 17,000 persons per year over the period 1954-1958 and reaching a peak in 1957-1958 with the takeover of most remaining Dutch enterprises. The migration of Chinese is more difficult to document. Foreign Chinese citizens have at various times been forced to move by government regulations which have limited their business activities and even right of residence in certain areas. The most important of these was the November 1959 regulation forbidding aliens from engaging in retail trade in rural areas (i.e., all areas outside kotapradja and kabupaten capitals). In the crisis which followed, large-scale repatriation to China took place, mainly from Java. Net emigration of Chinese, which had amounted to only a few thousands per year in the $1950^{\prime}$ 's, rose to 100,000 in 1960.48 Other effects have not been closely studied. Skinner mentions a probable net migration into Java from the Outer Islands, 49 and it is likely there was also some redistribution resulting in a greater concentration of Chinese in the large cities. The enforcement of regulations restricting the Chinese has been regionally diverse and erratic, as popular anti-Chinese sentiment is greater in some areas than in others; moreover, implementation has been affected at times by requirements of foreign policy and an implicit recognition of the economic disruption which would follow full compliance with the rules.

Apart from actions initiated or endorsed by the central government, movements of foreign Chinese have been caused by sporadic violent outbreaks of antisinicism in various regions, particularly those, such as Atjeh and parts of East and West Java, with strongly Muslim populations. Local military commanders have sometimes focussed discontent by issuing harassing regulations in their own districts. In disturbances of this sort, Indonesian citizens of Chinese descent have often been regarded as de facto foreign nationals, a situation encouraged by confusion over the Dual Nationality Treaty signed with China in 1955. In the most recent case, in Atjeh in 1966, there was a literal expulsion of over 10,000 foreign Chinese from that

48. Department of Immignation data quoted in Statistical Pocketbook of Indonesia, 1963 (Djakarta: Biro Pusat Statistik).

49. G. William Skinner, "The Chinese Minority," in Ruth McVey (ed.), Indonesia (New Haven: HRAF, 1963), p. 99. 
province; most of them fled to Medan, whence some 4,000 were repatriated to China.

\section{OUTMIGRATION FROM JAVA}

In the previous section a brief description was given of the more important short-term population movements since 1950, in order that allowance for them may be made when considering long-term migratory trends. Such an allowance is particularly necessary if meaningful statements are to be made based on the 1961 census birthplace data. The usual procedure of comparing results on place of birth from two successive censuses breaks down in Indonesia's case because of the thirty-year gap, spanning war and revolution, combined with a short and not accurately known life expectancy. The 1964/65 National Sample Survey can be used as an aid in evaluating the census results. One advantage of this survey was that its reference period, 1960-1964, was a time when the country was relatively secure internally. Unfortunately the proportion of migrants in the population is so small that the sampling errors are frequently obtrusive: even the broad geographical division into fourteen statistical regions 50 often gives units too small to be considered individually. The omission of Djakarta Raya is a major deficiency, and although in the appendix to this article I have attempted to estimate inmigration to the capital, Djakarta is so dominant as a recipient area that the lack of any more accurate information on it should be kept well in mind.

In terms of net interregional migration, 51 the flows shown up in the National Sample. Survey are summarized in Figure 1 . It is clear that the only resultant movements of numerical consequence are those to and from Java, and that of these outmigration from Java is far more important than movement to that island. This is the first postwar answer to the question of whether net migration to Java is positive or negative. Considered in gross terms migration to and from Java is indeed negligible, as most writers have assumed, 52 both as a proportion of Java's population and relative to the number of inhabitants of the Outer Island regions. It is only when we look more closely at smaller spatial units and at the specific characteristics of migrants compared to the rest of the population that a sharper picture emerges.

50. Those given in Table 5 together with Maluku.

51. Because of the importance of the distinction between urban and rural origins and destinations of migrants, the usefulness of estimating net totals is limited.

52. See, for example, Vaino Kannisto, Population Increase in Indonesia (Djakarta: Central Bureau of Statistics, 1963), PP. 8-9. 
FIG. 1: DIAGRAMMATIC CHART OF NET MIGRATION BETWEEN MAJOR REGIONS OF INDONESIA (EXCLUDING EAST NUSATENGGARA, MALUKU, AND WEST (RIAN), AVERAGE 1960- 1964

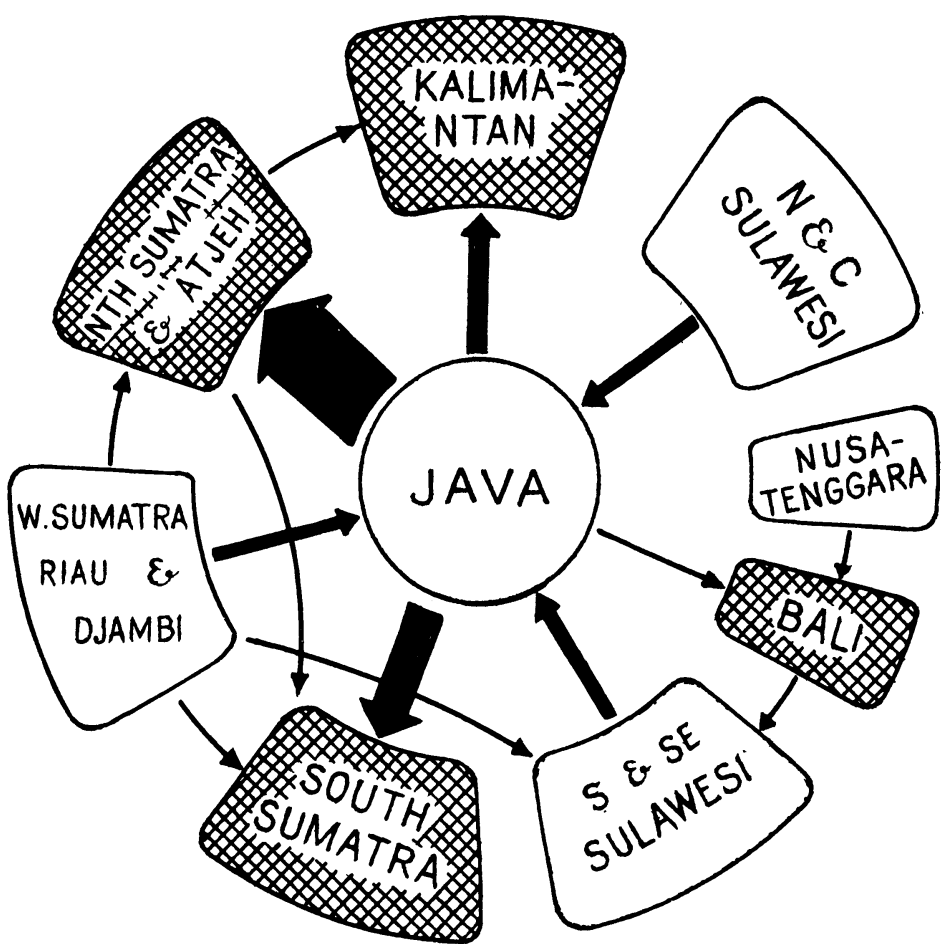

Regions of net inmigration

$\square$ Regions of net outmigration

Source: National Sample Survey, 1964/65 and estimates of inmigration to Djakarta Raya 
The National Sample Survey estimated that some 419,000 people living in the Outer Islands in 1964 had moved there from Java within the previous five years, 152,000 of them in 1964 itself. Taking into account the short-term nature of much of this migration (see Table 4) and assuming a linear "leakage" back to Java, 53 it seems likely that there was an average annual outflow of about 140,000 people from Java over the years 1960-1964, with less than 40,000 persons staying longer than five years. The 1930 census recorded 825,000 Java-born Indonesians in the Outer Islands, while by 1961 the number in rural areas alone had risen to 1.35 million. 54 If the 1961 birthplace figures are reflected in the current migration pattern, which shows a ratio of $2: 7$ between urban and rural interisland migrants, this would imply that altogether in 1961 there were over 1.9 million Java-born Indonesians in the outer Islands. Alternatively, if the proportion of Java-born in each Outer Island province was the same in both its rural and urban sectors, the total would be 1.6 million. 55 Clearly either the National Sample Survey has underestimated the numbers of migrants or at some time in the past the flow must have considerably exceeded the 1960-1964 average; but without details on the age distribution of these Java-born migrants it is difficult to say more.

The census totals of outmigrants from Java in rural areas of the Outer Islands, supplemented by the estimates for urban areas taken from the appendix, are shown in Figure 2. Sumatra continues to receive the overwhelming majority: of all Java-born Indonesians enumerated in the Outer Islands in 1930, 92.2 percent were in Sumatra, and of the Java-born in rural areas of the Outer Islands in 1961, 92.8 percent lived in Sumatra. (In the latter year, 4.4 percent were in Kalimantan, 1.6 percent in Sulawesi, and 1.2 percent in Nusatenggara and Maluku.) The big change has been the growth of the Java-born population in Lampung from 91,000 , or 26 percent of the local population in 1930, to about 585,000 in rural areas alone--40 percent of the rural population of Lampung in 1961 (see Table 7). The extent to which this growth has been due to organized and spontaneous migration will be discussed below.

53. See the appendix for a discussion of the bases for making the assumption.

54. 1961 census, 90 percent sample.

55. This assumption has been made in the estimate given in Appendix 3 and applied in Figure 2. The numbers of ethnic Javanese, Sundanese, and Madurese in the Outer Islands would of course include most descendants of migrants and would thus be much greater. In 1930 the ethnic total was estimated at 1.151 million (Volkstelling 1930 (VIII), p. 45), some 40 percent more than the total Java-born. 


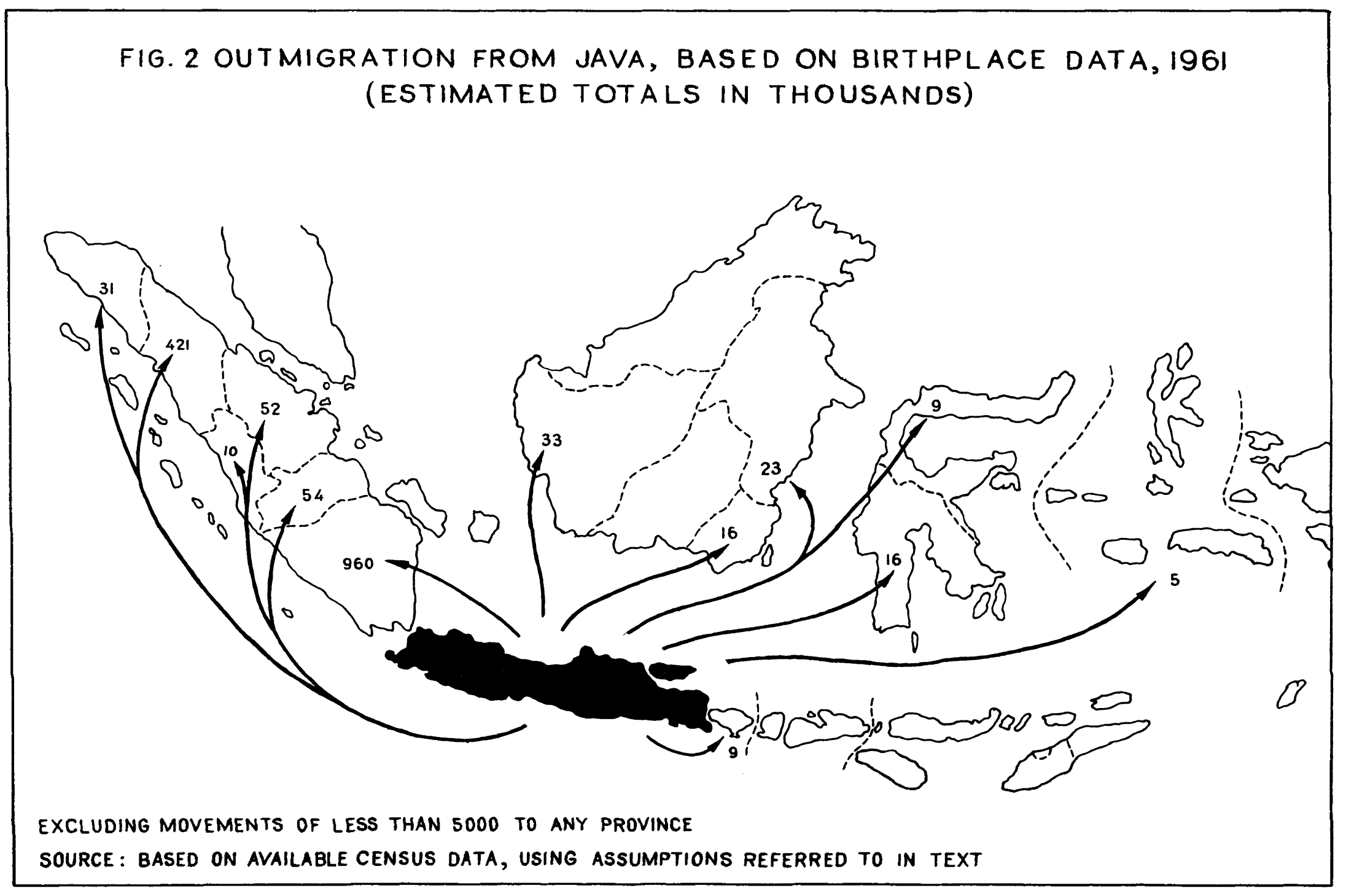


Table 7. Distribution of Java-born Population in Sumatra, $1930^{a}$ and 1961 .

\begin{tabular}{|c|c|c|c|c|}
\hline \multirow[b]{2}{*}{ Province ${ }^{b}$} & \multicolumn{2}{|c|}{1930} & \multicolumn{2}{|c|}{1961 (rural areas) } \\
\hline & No. & $\%$ & No. & $\%$ \\
\hline Atjeh & 48,168 & 6.3 & 29,000 & 2.3 \\
\hline North Sumatra & 470,676 & 61.3 & 348,000 & 27.9 \\
\hline West Sumatra & 34,873 & 4.5 & 8,000 & 0.6 \\
\hline Riau & 17,892 & 2.3 & 47,000 & 3.8 \\
\hline Djambi & 12,516 & 1.6 & 41,000 & 3.3 \\
\hline South Sumatra & 92,484 & 12.1 & 191,000 & 15.3 \\
\hline Lampung & 90,871 & 11.9 & 585,000 & 46.8 \\
\hline Total Sumatra & 767,570 & 100.0 & $1,249,000$ & 100.0 \\
\hline
\end{tabular}

a. Indonesians only.

b. Boundaries as in 1964 .

Source: Based on data in Volkstelling 1930, (IV), Pp. 180-18I, and 1961 census, 90 percent sample.

Other areas where migrants from Java comprise a significant proportion of the population are shown in Table 8 and, diagrammatically, in Figure 3. In South Sumatra the kabupaten of Ogan Komering Ulu, Musi Rawas, and Redjang Lebong in the estate areas east of the Bukit Barisan had a large Javanese population before 1930 ; this increased rapidly with the stepping up of the colonization program in the late $1930^{\prime} \mathrm{s}$ ( North Sumatra the historic estate areas of Langkat, Deli Serdang, Asahan, and Labuhan Batu still contain large numbers of Java-born inmigrants but the inflow relative to the local population seems to have slackened since the war. 56 The high sex ratio recorded for the Java-born population of Lahat may be due to the pioneering work of opening forest land by male migrants whose families have remained in the more established settlements in Musi Rawas Batanghari and Bengkalis kabupaten on the eastern coast of Sumatra also show a predominance of male inmigrants. Outside

56. The decline in the proportion of Java-born must be attributed mainly to the Toba Batak migration discussed above. In 1930 the proportions of inmigrants from Java in these kabupaten were 37.6 percent for Langkat, 38.6 percent for Deli Serdang, and 35.5 percent for Asahan and Labuhan Batu combined. Volkstelling 1930 (IV), p. 180. 


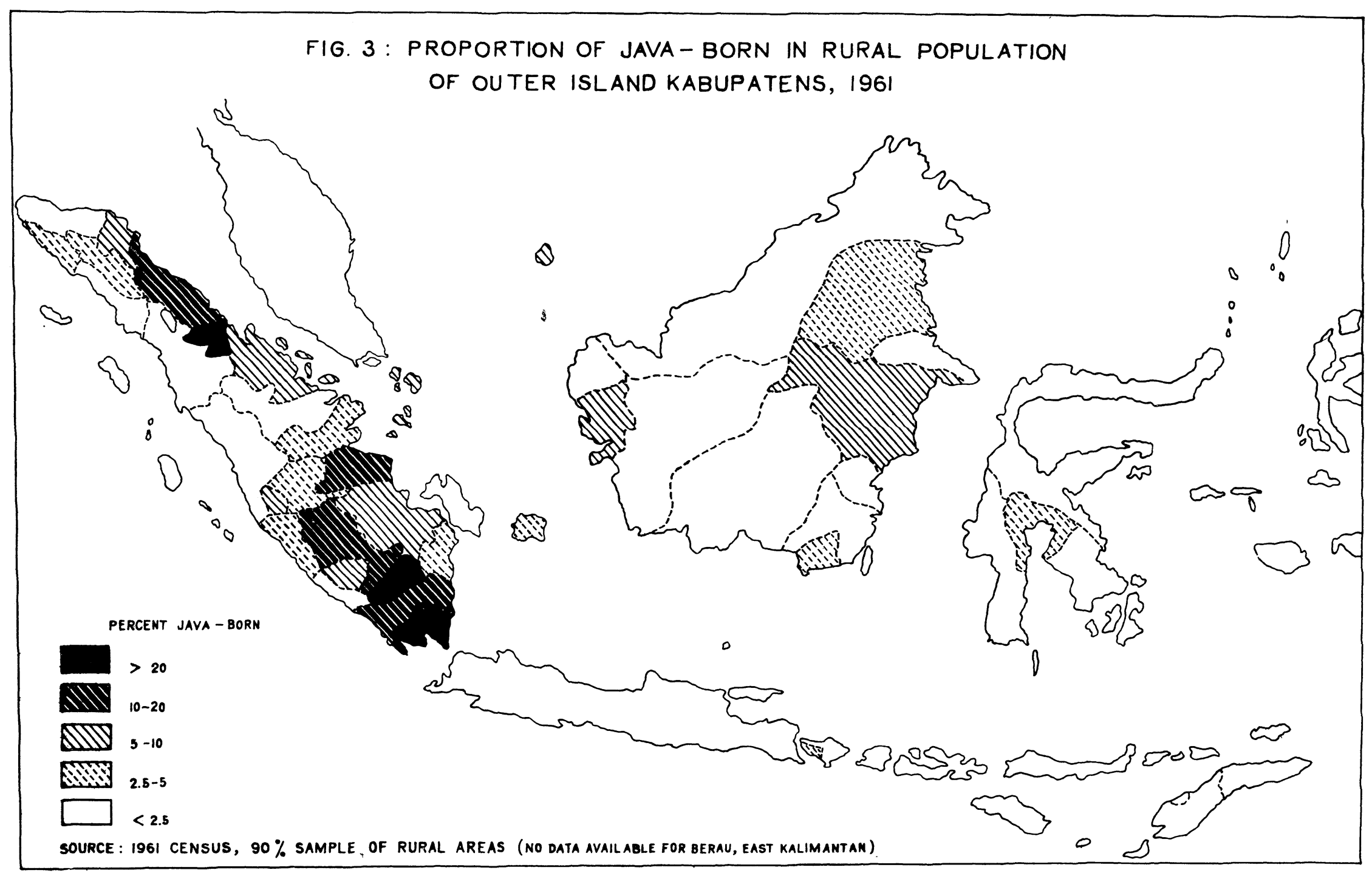


Sumatra, only small numbers of Java-born outmigrants were recorded in 1961, though sometimes the sparseness of the indigenous population means that they form a relatively substantial group; this is true, for example, in East Kalimantan. The Java-born are found largely in transmigration settlement areas: Luwu in South Sulawesi, and Pontianak, Bandjar, and southeast Kutai in Kalimantan.

Table 8. Percentage and Sex Ratio of Java-born Inmigrants in the Population of Rural Areas of Selected Outer Island Kabupaten, $1961^{\mathrm{a}}$

\begin{tabular}{|c|c|c|c|c|c|}
\hline \multirow[b]{2}{*}{$\begin{array}{l}\text { Province } \varepsilon \\
\text { kabupaten }\end{array}$} & \multicolumn{2}{|c|}{ Java-born } & \multirow[b]{2}{*}{$\begin{array}{l}\text { Province } \varepsilon \\
\text { kabupaten }\end{array}$} & \multicolumn{2}{|c|}{ Java-born } \\
\hline & $\%$ & $\begin{array}{l}\text { Sex } \\
\text { ratio }\end{array}$ & & $q$ & $\begin{array}{l}\text { Sex } \\
\text { ratic }\end{array}$ \\
\hline Lampung & & & North Sumatra & & \\
\hline $\begin{array}{l}\text { Lampung Selatan } \\
\text { Lampung Tengah } \\
\text { Lampung Utara } \\
\text { South Sumatra }\end{array}$ & $\begin{array}{l}38.9 \\
55.1 \\
15.2\end{array}$ & $\begin{array}{l}1209 \\
1138 \\
1314\end{array}$ & $\begin{array}{l}\text { Asahan } \\
\text { Deli Serdang } \\
\text { Labuhan Batu } \\
\text { Langkat } \\
\text { Simalungun }\end{array}$ & $\begin{array}{l}15.5 \\
11.9 \\
20.5 \\
14.6 \\
13.4\end{array}$ & $\begin{array}{l}1162 \\
1096 \\
1180 \\
1145 \\
1071\end{array}$ \\
\hline $\begin{array}{l}\text { Lahat } \\
\text { Musi Banjuasin } \\
\text { Musi Rawas } \\
\text { Ogan Komering Ulu } \\
\text { Redjang Lebong }\end{array}$ & $\begin{array}{r}5.4 \\
8.2 \\
15.5 \\
22.0 \\
10.9\end{array}$ & $\begin{array}{l}2933 \\
1237 \\
1323 \\
1183 \\
1404\end{array}$ & $\begin{array}{l}\frac{\text { Atjeh }}{\text { Atjeh Timur }} \\
\text { West Kalimantan }\end{array}$ & 7.8 & 1187 \\
\hline Djambi & & & Pontianak & 5.3 & 1317 \\
\hline $\begin{array}{l}\text { Batanghari } \\
\text { Kerintji }\end{array}$ & $\begin{array}{r}10.9 \\
5.0\end{array}$ & $\begin{array}{l}2176 \\
1083\end{array}$ & $\frac{\text { East Kalimantan }}{\text { Kutai }}$ & 5.1 & 1420 \\
\hline Riau & & & & & \\
\hline Bengkalis & 5.0 & 2423 & & & \\
\hline
\end{tabular}

a. Covering kabupaten with a Java-born population of 5 percent or more of the rural population. Luwu kabupaten in South Sulawesi had 6.6 percent Java-born in the enumerated population, but large areas were not covered by the census due to insecurity; enumerated Java-born comprised only 2.4 percent of total estimated population. No data are available for Berau in East Kalimantan.

Source: Based on results of 1961 census, 90 percent sample.

Where do the migrants come from? In 1930 it was possible to answer in some detail. The main areas of outmigration to the East Coast of Sumatra were the residencies of Kedu and Banjumas in Central Java, Kediri, Surabaja, and Madiun in East Java, and 
the governments of Jogjakarta and Surakarta. Java-born inhabitants of Lampung came mostly from Banten in West Java and Kedu. In other parts of Sumatra, such as Palembang, the West Coast, and Atjeh, the places of birth of migrants were distributed more evenly among residencies in Java. The only other Outer Island residency with many Java-born inhabitants, South/East Borneo, drew two-thirds of them from East Java, especially Surabaja and Kediri. 57

On the basis of the 1961 census it can only be stated definitely that Central Java remained the most important donor region for migrants to Sumatra, providing half the Java-born in both South Sumatra (including Lampung) and North Sumatra; East Java made up a little over half the remainder (see Table 9 ). In the provinces of eastern Indonesia migrants from East Java predominate, except in East Kalimantan, where there is a small majority from Central Java. Despite the lack of detail in the 1961 census on place of origin, we can reasonably suppose that since prewar times the pressures influencing migration--for example, the decline in the cash crop sector--have changed in intensity rather than kind, and consequently that the 1930 picture remains generally valid.

Sex ratios in the donor areas, which may indicate roughly the extent of total outmigration, suggest that in 1961 Banten had declined in importance as a sending region for migrants. 58 The residencies 59 with the least masculine sex ratios in 1961 were Madura (886), Pekalongan (917), Kedu (927), Tjirebon (935), Malang (935), Madiun (938), Jogjakarta (934), and Surabaja (943).60 In the case of Madura, the very low ratio is almost certainly due to the continuation of longstanding outmigration to Besuki, particularly to Djember, which shows a correspondingly

57. The number of outmigrants in the Outer Islands as a percentage of the enumerated population in their residency of birth in 1930 was 4.55 percent for Banten, 6.04 percent for Kedu, 3.53 percent for Banjumas, 3.48 percent for Kediri, 2.50 percent for Surabaja, 2.14 percent for Madiun, 4.15 percent for Jogjakarta and 1.70 percent for surakarta. [Based on data in Volkstelling 1930 (VIII), PP. 94-95, Indonesians only.]

58. Its 1961 sex ratio was 982 , compared with the Java average of 953. In 1930 the Banten ratio was 939 and for Java 955 (for Indonesians only).

59. To simplify comparison with 1930 data, present-day kabupaten are grouped into the former residencies.

60. Sex ratios given for Jogjakarta territory and Surabaja residency exclude the cities of Jogjakarta and Surabaja. (Computed from preliminary census data published in census report S. P. I.) 
high sex ratio. 61 Similarly, Tjirebon and, to a lesser extent, Pekalongan residencies provide a considerable number of migrants to Djakarta who are predominantly male,62 and it can be guessed that Malang and Surabaja residencies stand in the same relationship to the city of Surabaja. The three important residencies of outmigration in 1930 which did not show low sex ratios in 1961 , Banjumas (961), Kediri (959), and Surakarta (951), had even higher ratios in 1930 (respectively, 964, 976, and 970). While it would be reasonable to expect some correlation between outmigration and sex ratios in a restricted age group, say 20-24, clearly the overall sex ratios do not tell us much.

Table 9. Origin of Java-born Migrants in Sumatra, 1930 and 1961

\begin{tabular}{|c|c|c|c|c|}
\hline \multirow[b]{2}{*}{ Residency/Province of Birth ${ }^{a}$} & \multicolumn{2}{|c|}{1930} & \multicolumn{2}{|c|}{1961 (rural areas) } \\
\hline & No. & $\%$ & No. & $\%$ \\
\hline $\begin{array}{l}\text { Banten } \\
\text { Priangan } \\
\text { Other West Java (incl. Batavia) } \\
\text { West Java \& Djakarta Raya }\end{array}$ & $\begin{array}{r}45,494 \\
34,893 \\
69,667 \\
150,054\end{array}$ & $\begin{array}{r}5.9 \\
4.5 \\
9.1 \\
19.5\end{array}$ & 230,000 & 18.4 \\
\hline $\begin{array}{l}\text { Banjumas } \\
\text { Kedu } \\
\text { Surakarta } \\
\text { Other Central Java } \\
\text { Central Java } \\
\text { D.I. Jogjakarta }\end{array}$ & $\begin{array}{r}69,458 \\
143,098 \\
40,285 \\
80,937 \\
333,778 \\
60,609\end{array}$ & $\begin{array}{r}9.0 \\
18.7 \\
5.2 \\
10.6 \\
43.5 \\
7.9\end{array}$ & $\begin{aligned} 672,000 \\
57,000\end{aligned}$ & $\begin{array}{r}53.8 \\
4.6\end{array}$ \\
\hline $\begin{array}{l}\text { Kediri } \\
\text { Madiun } \\
\text { Surabaja } \\
\text { Other East Java } \\
\text { East Java } \\
\text { Unknown }\end{array}$ & $\begin{array}{r}72,483 \\
37,340 \\
40,711 \\
50,661 \\
201,195 \\
21,934 \\
\end{array}$ & $\begin{array}{r}9.4 \\
4.9 \\
5.3 \\
6.6 \\
26.2 \\
2.9 \\
\end{array}$ & $\begin{array}{c}290,000 \\
\ldots\end{array}$ & $\begin{array}{c}23.2 \\
-- \\
\end{array}$ \\
\hline $\begin{array}{l}\text { Java } \\
\text { a. Residency/government boundari } \\
\text { Residual categories for each } \\
\text { bers whose residency of birth }\end{array}$ & $\begin{array}{l}767,570 \\
\text { es as in } \\
\text { province } \\
\text { was not }\end{array}$ & $\begin{array}{l}100.0 \\
1930 ; p \\
\text { in } 1930 \\
\text { stated. }\end{array}$ & $\frac{1,249,000}{\text { rovinces as }}$ & $\begin{array}{l}\frac{100.0}{1961 .} \\
1 \text { num- }\end{array}$ \\
\hline $\begin{array}{l}\text { b. Outer Island enumerated popul } \\
\text { not further specified. }\end{array}$ & ation of & unknown & birthplace w & as \\
\hline $\begin{aligned} \text { Source: } & \text { Based on data in Volkste } \\
& 1961 \text { census, } 90 \text { percent }\end{aligned}$ & $\frac{\text { lling } 193}{\text { sample. }}$ & $30(I V)$, & pp. 40-41; a & nd \\
\hline
\end{tabular}

61. Although Madura has a population density of only 393 persons per square kilometer, low by East Java standards, the proportion of irrigated land is only half the East Java average ( 9.9 percent compared to 19.7 percent for East Java--Sensus Pertanian 1963). Mainland East Java has a considerable floating population of Madurese who return periodically to their families on Madura.

62. Heeren, op. cit., p. 10. The sex ratio of short range urban migrants $\mathrm{w} i l \bar{l}$ be examined below; West Java-born migrants in Djakarta in 1961 had a sex ratio of 1006. 
An examination of the age distribution of outmigrants given by the National Sample Survey reveals some interesting features. One-third of the migrants are in the age group 20-29,63 compared to less than 15 percent for the population as a whole. On the other hand, the age group 10-19 is relatively empty, particularly for migrants to rural areas of the Outer Islands, among whom it comprises less than half the pnoportion shown in the general population. The distribution is given in Table 10 together with the corresponding distributions for the whole of Java and the Outer Islands.

Table 10. Percentage Age Distributions of 1960-1964 Interisland Migrants and Total Population, Java and Outer Islands, $1964^{2}$

\begin{tabular}{|c|c|c|c|c|}
\hline \multirow[b]{2}{*}{$\begin{array}{l}\text { Age } \\
\text { Group }\end{array}$} & \multicolumn{2}{|c|}{ Total Population } & \multicolumn{2}{|c|}{ Interisland Migrants } \\
\hline & Java & $\begin{array}{l}\text { Outer } \\
\text { Islands }\end{array}$ & $\begin{array}{c}\text { Java to Outer } \\
\text { Islands }\end{array}$ & $\begin{array}{c}\text { Outer Islands } \\
\text { to Java }\end{array}$ \\
\hline $\begin{aligned} 0 & -9 \\
10 & -14 \\
15 & -19 \\
20 & -24 \\
25 & -34 \\
35 & -44 \\
45 & -54 \\
55 & -\end{aligned}$ & $\begin{array}{r}32.2 \\
10.6 \\
7.1 \\
6.6 \\
15.6 \\
12.9 \\
8.3 \\
6.6\end{array}$ & $\begin{array}{r}34.2 \\
11.6 \\
8.7 \\
6.8 \\
13.5 \\
11.1 \\
7.2 \\
6.8\end{array}$ & $\begin{array}{r}25.5 \\
6.0 \\
6.0 \\
16.7 \\
28.1 \\
11.0 \\
3.6 \\
3.1\end{array}$ & $\begin{array}{r}(22.3) \\
(12.3) \\
(10.8) \\
(7.7) \\
(20.7) \\
(15.4) \\
(7.7) \\
(3.1)\end{array}$ \\
\hline Unknown & 0.1 & 0.1 & -- & -- \\
\hline Total & 100.0 & 100.0 & 100.0 & 100.0 \\
\hline
\end{tabular}

a. Excluding Djakarta Raya, East Nusatenggara, Maluku, and West Irian in total distributions and as destinations of interisland migrants.

Note: Figures in parentheses should be regarded as very approximate due to the smallness of the sample.

Source: Based on National Sample Survey, 1964/65.

63. The National Sample Survey recorded the ages of all migrants over the previous five years as of the end of 1964. Thus the resulting age distributions are slightly blurred as an indicator of the ages of migrants at the time of migration. The defect is not of great significance, as the median time of migration falls in 1963 due to the predominance of short term movements. 


\section{Transmigration}

If we are to discuss this outmigration in more detail we must first consider what sort of people the migrants are. Organized migration from Java covers the government's transmigration program and the recruitment of contract labor for estates and other enterprises in the Outer Islands, which is now supervised by the Department of Labor. Apart from this controlled movement there is "spontaneous" and "free" transmigration, 64 in which the role of the authorities, at least in Java, is reduced or nonexistent. Finally, there is some migration of Outer Island-born residents of Java back to their home regions.

The term "transmigration" covers a number of systems under which new agricultural land is opened up or improved by irrigation facilities for settlement by people from overpopulated areas. As I remarked earlier, there is a considerable literature on the subject, partly aimed at pointing out the futility of such programs as a means of solving the problems of overpopulation in Java and arguing that they risk merely reproducing in the settlement areas a society with the same intractable obstacles to development as occur in rural Java.

The prewar program, 65 known as colonization, was begun on an experimental scale in 1905 but remained very small until the 1930's (see Table 1l). The earliest migrant colonies were established in the residencies of Lampung (1905) and Bengkulu (1908), while a short-lived attempt was made in Kalimantan in 1921. Much later, between 1937 and 1941, other settlements were founded

64. Transmigrasi spontan and transimgrasi liar (vrije transmigratie). Some confusion has arisen through the use of "spontaneous" in different senses: Some writers (e.g., Kampto Utomo, op. cit.) use the term in a general sense to cover all migration not arranged and financed by the Transmigration Service or another government body. However, it is also used [e.g., by Soedigdo Hardjosudarmo, Kebidjaksanaan Transmigrasi dalam Rangka Pembangunan Masjarakat Desa di Indonesia (Djakarta: Bhratara, 1965); and by the Transmigration Service itself] to refer specifically to migrants approved by the service who to avoid delays pay their own passage to the settlement area and subsequently receive the same facilities as general transmigrants. These are also called "transmigran dengan biaja sendiri"--transmigrants at own expense. With the latter usage, migrants who move entirely without the knowledge of the authorities are termed "transmigran liar." In this discussion, "spontaneous" is used in the former, nonspecific, sense.

65. For detailed descriptions, see Karl J. Pelzer, Pioneer Settlement in the Asiatic Tropics (New York: American Geographical Society, 1948), pp. 191-227; and Amral Sjamsu, op. cit., pp. 5-77. 
Table 11. Numbers of Sponsored Migrants Arriving in Settlement Areas, 1905-1963

\begin{tabular}{|c|c|c|c|}
\hline & Number of & Settlers & \\
\hline Period & Total & $\begin{array}{l}\text { Annual } \\
\text { Average }\end{array}$ & Migration Scheme \\
\hline $1905-1911$ & 6,500 & 860 & $\begin{array}{l}\text { Colonization (experimental phase); } \\
\text { all expenses paid by N.E.I. govern- } \\
\text { ment. }\end{array}$ \\
\hline $1912-1922$ & 16,838 & 1,531 & Colonization; settlers financed by \\
\hline $1923-1931$ & c. 4,000 & 440 & $\begin{array}{l}\text { Lampongsch Volksbank (liquidated } \\
\text { in 1928). }\end{array}$ \\
\hline $1932-1941^{\mathrm{a}}$ & 162,600 & 16,260 & $\begin{array}{l}\text { Colonization (large scale); new } \\
\text { settlers supported by old settlers } \\
\text { on bawon system. }\end{array}$ \\
\hline $1950-1963$ & 323,459 & 23,104 & $\begin{array}{l}\text { Transmigration; transmigran-keluarga } \\
\text { (families nominated and initially } \\
\text { supported by old settlers) and } \\
\text { transmigran-umum (financed by loans } \\
\text { from Transmigration Service). }\end{array}$ \\
\hline
\end{tabular}

a. No settlers were moved in 1933, making the average for the nine years when the bawon system actually operated $18067 \mathrm{p} . \mathrm{a}$.

b. Data also cover several smaller categories of migrants: transmigrants at own expense, local transmigrants, war veterans, exromushas and repatriates from suriname.

Source: 1905-1955, compiled from data in Amral sjamsu, op. cit., pp. 106f; 1956-1963, Djawatan Transmigrasi data published by the Biro Pusat Statistik.

in Palembang, Djambi, and the West Coast residencies of Sumatra, near Bandjarmasin in Kalimantan, and near Parepare in Sulawesi. The numbers of settlers moved were small except to the colonies in Lampung, which received nearly 80 percent of the total up to 1937 and 60 percent in the years 1938-1940. (Palembang received 15 percent of the transmigrants and southern Sulawesi 18 percent in 1938-1940; see Table 12.) The sponsored migrants also generated a substantial spontaneous flow of settlers from Java, again almost all to Lampung. The 1930 census recorded 120,641 Javanese and Sundanese in Lampung, compared to 180,160 Lampungese. 66 But by 1941 one estimate put the relative totals at 245,000 and 215,000 , with about 174,000 of the former figure colonists in the

66. Volkstelling 1930 (IV), p. 106. 
Table 12. Distribution of Transmigrants in Settlement Areas, Pre- and Post-war Periods

\begin{tabular}{|c|c|c|c|c|c|c|}
\hline \multirow[b]{3}{*}{ Settlement Region ${ }^{a}$} & \multirow{2}{*}{\multicolumn{2}{|c|}{$\begin{array}{c}\text { Distribution as } \\
\text { at end-1937 }\end{array}$}} & \multicolumn{4}{|c|}{ Destination of Migrants: } \\
\hline & & & \multicolumn{2}{|c|}{$1938-1940$} & \multicolumn{2}{|c|}{$1950-1959^{b}$} \\
\hline & No. & $\%$ & No. & $\%$ & No. & $\%$ \\
\hline $\begin{array}{l}\text { Lampung } \\
\text { South Sumatra } \\
\text { (Res. Palembang) } \\
\text { (Res. Bengkulu) } \\
\text { Djambi } \\
\text { West Sumatra } \\
\text { North Sumatrac }\end{array}$ & $\begin{array}{c}73,499 \\
9,825 \\
(2,455) \\
(7,370) \\
-- \\
-- \\
9,765\end{array}$ & $\begin{array}{l}78.0 \\
10.4 \\
(2.6) \\
(7.8) \\
-- \\
-- \\
10.4\end{array}$ & $\begin{array}{c}78,483 \\
21,179 \\
(19,519) \\
(1,660) \\
1,945 \\
-\overline{2,138}\end{array}$ & $\begin{array}{c}60.2 \\
16.3 \\
(15.0) \\
(1.3) \\
1.5 \\
-- \\
1.6\end{array}$ & $\begin{array}{c}77,627 \\
74,214 \\
(67,070) \\
(7,144) \\
-- \\
4,593 \\
4,232\end{array}$ & $\begin{array}{c}42.6 \\
40.8 \\
(36.9) \\
(3.9) \\
-- \\
2.5 \\
2.3\end{array}$ \\
\hline Sumatra & 93,089 & 98.8 & 99,745 & 79.6 & 160,666 & 88.2 \\
\hline Kalimantan & -- & -- & 2,976 & 2.3 & 15,312 & 8.4 \\
\hline Sulawesi & 1,089 & 1.2 & 23,580 & 18.1 & 4,989 & 2.8 \\
\hline Nusatenggara & -- & -- & -- & -- & 252 & 0.1 \\
\hline Maluku & -- & -- & - & -- & 851 & 0.5 \\
\hline Total & 94,178 & 100.0 & 130,301 & 100.0 & 182,070 & 100.0 \\
\hline
\end{tabular}

a. Provinces as in 1964 .

b. To June 1959; excluding 5,032 local transmigrants in West Java.

c. Prewar figures are for settlements on estate concession land not regarded as proper colonization settlements.

Source: Based on data in Indisch Verslag 1941 and Garis-garis Besar Pola Pembangunan Nasional Semesta Berentjana (Djakarta: Dewan Perantjang Nasional, 1960)

(XII), PP. 254l-2547. 
settlement areas. 67 While some of the Javanese and Sundanese outside the settlements may have come originally as sponsored migrants or contract workers or have been descendents of such persons, the great majority are likely to have been spontaneous migrants.

The primary object of colonization was to reduce overpopulation in Java.68 official calculations showed this to be feasible with what was then thought to be a realistic expansion of the program: a constant natural increase of 1.5 percent in Java's population, with an annual outmigration of 80,000 families (young married couples with one child), would mean that by the year 2000 the island's population would reach 74 million, compared with 116 million with no migration. 69 Although in the peak year of 1940 less than a fifth of this number of families was moved by the authorities, the concomitant spontaneous migration was becoming increasingly significant.

Accepting the stated goal for outmigration, its measure of success is indeed, as Keyfitz has argued of the postwar program, 70 the degree to which sponsored migration generates a spontaneous flow. However, the process should perhaps be seen in broader perspective. It was widely recognized that large-scale migration could not continue indefinitely, and that the establishment of subsistence-level Javanese villages in the Outer Islands was not a particularly useful end. Pelzer has pointed out the importance of Outer Island development in creating a market for

67. Amral Sjamsu, op. cit., p. 18. The 245,000 are described only as "rakjat dari Djawa," but are distinguished from Bantenese. The colonists at least were all from Central and East Java.

68. Amral Sjamsu (op. cit., pp. 122-124) argues strongly that the purpose was rather to establish a permanent, cheap source of labor for present and future capitalist enterprise in the Outer Islands; he links the reawakening of interest in colonization in the late 1920's to fears of the consequences of the abolition of penal sanctions. While this was true of the North Sumatran case and of the small colonies of foresters at Martapura, Samarinda, and Muna, it is difficult to reconcile such a motive with the competition which existed up to the Depression between estate companies and the colonization authorities in recruiting potential migrants.

69. Quoted by Pelzer, op. cit., p. 211.

70. Nathan Keyfitz, "Recommendations for Population Study and Demographic Research in Indonesia," Warta Leknas (II, 3), 1964 . 
Java's industries, ${ }^{71}$ which suggests that investment in migration should have been restricted to cases where a labor input was needed for such development.

When organized interisland migration was resumed in 1950 under the name of transmigration, the objectives were restated more in accord with this viewpoint. Although the notion tended to persist, it was no longer credible to propose migration as a solution to overpopulation except in small localized situations. The relevent ministerial decisions and government decrees gave equal weight to other reasons: the promotion of economic development, security, and national unity. ${ }^{72}$ The numbers of migrants never exceeded the 1940 total in any postwar year, averaging about 23,000 over the period 1950-1963. However, a greater proportion of migrants were sent to settlements other than those in Lampung--particularly to Belitang and Tugomuljo (in the kabupaten of Ogan Komering Ulu and Redjang Lebong, South Sumatra) but also to new settlements in Kalimantan, Sulawesi, and Maluku.

No census figures are as yet available on the age distribution of the inmigrant population of Lampung or the other settlement regions, but some information concerning ages of officially sponsored migrants at the time of their move has been recorded by the Transmigration Service. The published figures are unfortunately classified only into broad age groups; the distribution computed from them for sponsored transmigrants (transmigran-umum) is given in the first three columns of Table 13. An interesting contrast is provided by some data on spontaneous migrants collected by Kampto Utomo in his study of a migrant community near W. Sekampung in South Lampung. He recorded the ages of all spontaneous migrants arriving at the town of sukohardjo, a transit center for various nearby settlements, in the first seven months of 1956. The total of nearly one thousand, almost all from Central Java, showed the age distribution given in the second part of Table 13 and in Figure 4. The number is rather small to give a basis for comparison, but there is a clear

71. Pelzer, op. cit., p. 230.

72. See, for example, Putusan Kementerian Sosial, February 2, 1951, and February 17, 1953; and Law no. 29, 1960. The latter states (chap. II, par. 2) that the objective of transmigration is "to raise the level of security, prosperity, and general welfare of the entire people and strengthen the feeling of unity of the Indonesian nation by means of: (a) exploitation of natural resources and opening of land in a regulated manner; (b) reduction of population pressure in regions of dense population and populating empty or sparsely inhabited regions; (c) populating and developing regions which play a vital role in achieving a higher level of national endurance in all fields of life; (d) the formation of a just and prosperous Indonesian socialist society." 
FIG. 4 : SPONTANEOUS TRANSMIGRANTS TO SUKOHARDJO, LAMPUNG SELATAN, 1956

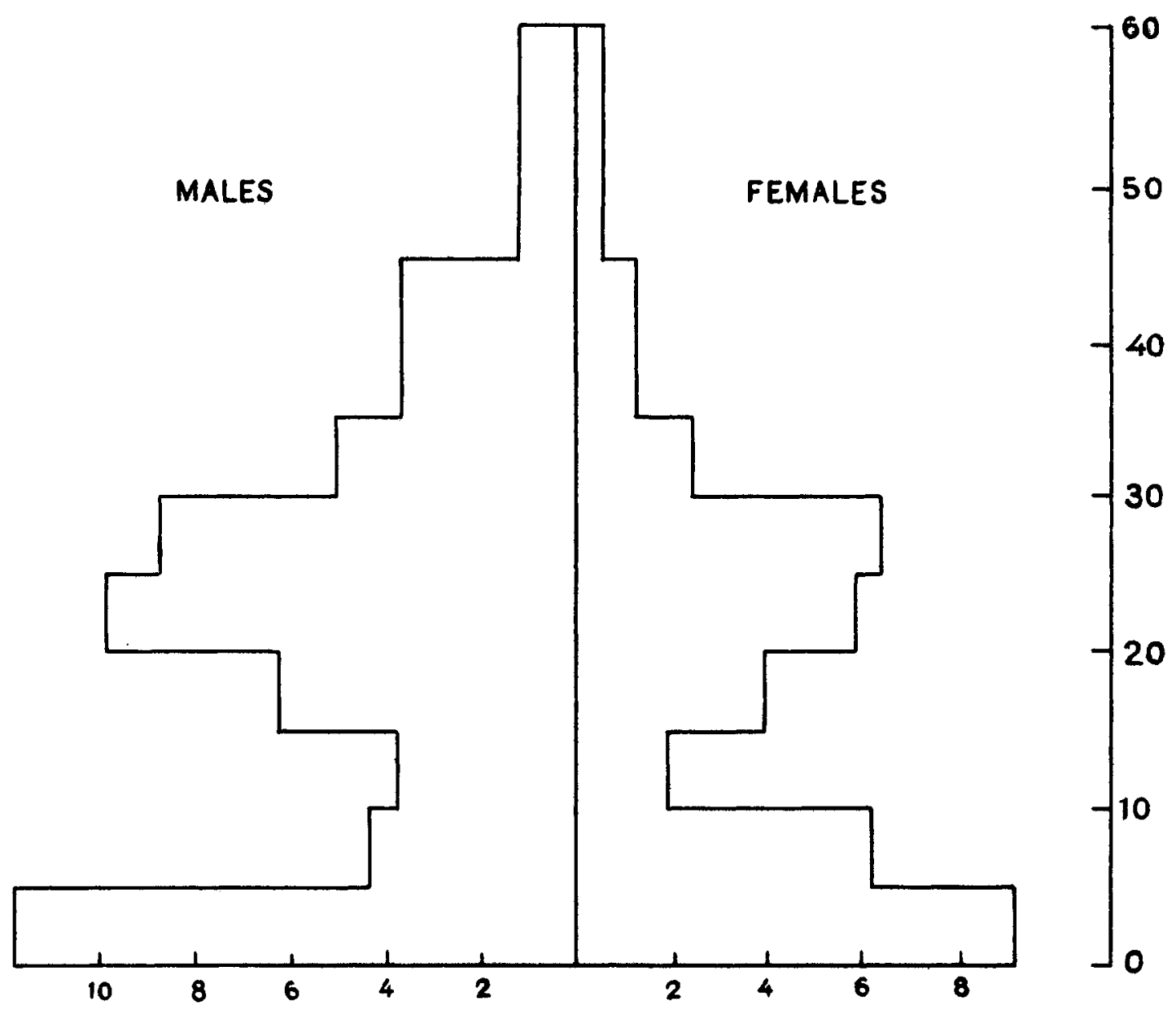


indication that the sex ratio is higher for spontaneous migrants than for those sponsored by the Transmigration Service, the difference being caused mainly by the large number of males in the middle age groups among the former. There is some similarity to the distribution of all outmigrants from Java in the years 1960-1964 (Table 10), but both categories of transmigrants include higher proportions of children.

Table 13. Percentage Age Distribution of Sponsored and Spontaneous Transmigrants to South Sumatra

\begin{tabular}{cccccccc}
\hline & \multicolumn{3}{c}{ Sponsored Migrants } & & \multicolumn{3}{c}{ Spontaneous Migrants } \\
\cline { 2 - 4 } $\begin{array}{c}\text { Age } \\
\text { Group }\end{array}$ & Males & Females & $\begin{array}{c}\text { Both } \\
\text { sexes }\end{array}$ & & Males & Females & $\begin{array}{l}\text { Both } \\
\text { sexes }\end{array}$ \\
\hline $0-4$ & 11.8 & 10.6 & 22.4 & & 11.7 & 9.1 & 20.8 \\
$5-14$ & 10.9 & 10.1 & 21.0 & & 8.1 & 8.0 & 16.1 \\
$15-49$ & 27.7 & 27.3 & 55.0 & & 39.2 & 21.6 & 60.8 \\
$50-$ & 0.9 & 0.7 & 1.6 & & 1.5 & 0.8 & 2.3 \\
Total & 51.3 & 48.7 & 100.0 & & 60.5 & 39.5 & 100.0 \\
\hline
\end{tabular}

a. Sponsored migrants: "transmigran-umum" settled in South Sumatra (incl. Lampung), 1951-1955; spontaneous migrants: migrants from Central Java arriving at Sukohardjo, South Lampung, January-July 1956.

Souce: Based on data in Transmigrasi 1951-1955 (Djakarta: Djawatan Transmigrasi, 1956), PP. 64-65, and Kampto Utomo, op. cit., p. 329.

The influence of Javanese migration to Lampung is clearly illustrated in the sex-age structure of the rural population. If we take as an example Central Lampung, which contains the highest proportion of inmigrants, we see a profile with a bulge at ages 25-44, combined with undercutting at 10-24. This more closely resembles the age pattern of Java than Sumatra: 30.5 percent of the kabupaten's rural population lies in the 2544 year range, compared with 29.2 percent for rural Java and 25.4 percent for all Sumatra. However, the sex ratios at the higher ages are considerably more masculine than those of either Sumatra or Java as a whole. In contrast the capital, Metro, does not have the empty age groups in the 10-24 range, suggesting that its population is less influenced by recent inmigration (see Figures 5 and 6 ). The situation in South Lampung is similar: the municipality of Tandjung Karang/Teluk Betung shows a distribution very like Metro, and the rural areas also resemble each other. 
FIG. 5 : POPULATION OF METRO, CAPITAL FIG. 6 POPULATION OF RURAL AREAS OF LAMPUNG TENGAH, 1961 OF LAMPUNG TENGAH, 1961
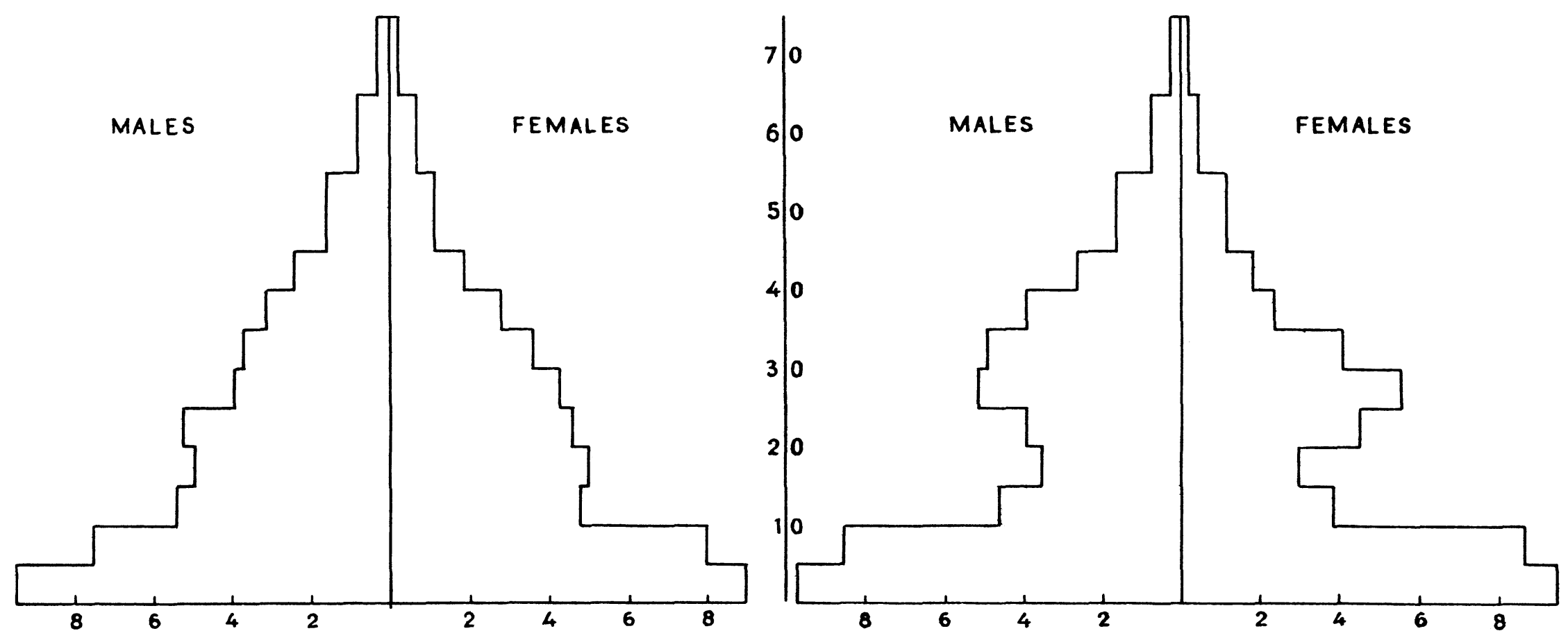

SOURCE: 1961 CENSUS, FINAL FIGURES 
Increasing economic difficulties have caused some disenchantment with the transmigration program, both because of its expense and because in many instances the settlers leave their holdings after a few seasons and move to nearby towns or, if possible, back to Java. It would seem that the program no longer occupies an important place in government policy, and the belated interest shown in family planning since 1966 will probably further reduce its priority. Nevertheless, there is every reason to expect a continuing and even increasing stream of spontaneous migrants. The danger here, as Wertheim and others have pointed out, 73 is that without careful and coordinated planning and a large investment in irrigation facilities and fertilizer, the conversion of swidden land into sawah is only a short intermediate stage before its deterioration and eventual surrender to alangalang grass.

\section{Contract Labor in the Outer Islands}

-Apart from the movement of agricultural settlers as sponsored or spontaneous transmigrants, Javanese have also left their homes as contract laborers recruited for estates and other enterprises in the Outer Islands. The system began in the mid-nineteenth century and at first employed Chinese from Singapore, Malaya, and south China; increasingly, however, Javanese were solicited. The contracts included the notorious poenale sanctie clauses, which were not made completely illegal until 1942. However, from the early part of the twentieth century, and. particularly after 1929,74 the proportion of free laborers steadily increased, while supervision by government inspectors lessened the abuses of the contract system. 75

In the 1920's some of the Sumatran East Coast estate companies attempted to establish Javanese settlements on concession land with the aim of providing a permanent labor pool. By the end of 1939 there were 11,000 such people settled in

73. See W. F. Wertheim, "Interisland Migration in Indonesia," in his East-West Parallels (The Hague: Van Hoeve, 1964), PP. $194-195$.

74. This was due to the labor surplus caused by the Depression, a U.S. Iaw prohibiting the import of products grown by labor subject to penal sanctions, and the increase of local Javanese settlers in the estate areas. See J. H. Boeke, Economics and Economic Policy of Dual Societies, as Exemplified by Indonesia (Haarlem: H.D. Tjeenk Willink, 1953), P. 158 .

75. At the end of 1940, the Outer Island estate labor force comprised 1.5 percent Chinese under contract, 5.5 percent free Chinese, 0.5 percent Javanese under contract, and 92.5 percent free Javanese. (Indisch Verslag 1941). 
what Pelzer called "pseudo-colonies"; 76 the families were only granted 0.1 hectare of land, so as to force them to work as laborers. 77 During and after the revolution most of these families probably staked out viable holdings on the concessions.

With independence and the resumption of estate production near its prewar level it again became necessary to recruit labor. The contracting system was reestablished with strict government supervision of contract terms. As with the prewar system, workers were encouraged to renew their contracts or to settle permanently in the area after the expiration of the stipulated--usually three year--period; but, also as before, the percentage of returnees remained high. ${ }^{78}$ In Table 14 the number of workers recruited annually since 1951 is given, together with the number of accompanying dependents (which are restricted to a maximum of two per married couple at working ages). 79 Over the whole period 1951-1966 the system provided an average labor force of 29,000 (assuming three year contracts, not extended), rising to 38,000 in the years 1960-1966 after the 1957-1959 nationalization measures. Nevertheless, a continued scarcity of labor existed. Blake quotes a Government Estates Administration report which estimated a shortage of 11,000 workers (1015 percent of total requirements) on government estates in early 1961.80 A more recent survey indicates that while there is presently a sufficient labor supply on rubber estates in North Sumatra, oilpalm estates have less than half the workers they need. 81

76. Pelzer, op. cit., p. 201.

77. Indisch Verslag 1941.

78. Interviews with Department of Labor officials, 1967. Estimates of the proportion of returnees are as high as 90 percent.

79. The coverage is incomplete as some unsupervised contracting admittedly takes place.

80. Donald Blake, "Labor Shortage and Unemployment in North East Sumatra," Ekonomi dan Keuangan Indonesia (XV, 1/2), 1962, P. 26.

81. Report to the Government of Indonesia of the I. L. O. Survey and Programme Planning Mission 1967 - 1968 U.N.D.P., 15 February - 15 March 1967 (Djakarta: I.L.0., 1967), p. 10. Maximum output for oilpalm estates is estimated to require 0.7 workers per hectare of planted areas, compared with the present 0.3 . 
Table 14. Recruitment of Javanese Contract Labor for Outer Island Enterprises, 1951-1966 (in thousands)

\begin{tabular}{lccccccr}
\hline \hline Year & $\begin{array}{c}\text { Work- } \\
\text { ers }\end{array}$ & $\begin{array}{c}\text { Depen- } \\
\text { dents }\end{array}$ & Total & Year & $\begin{array}{c}\text { Work- } \\
\text { ers }\end{array}$ & $\begin{array}{c}\text { Depen- } \\
\text { dents }\end{array}$ & Total \\
\hline 1951 & 10.6 & 7.8 & 18.4 & 1959 & 3.2 & 2.0 & 5.2 \\
1952 & 13.6 & 9.3 & 22.9 & 1960 & 10.9 & 6.8 & 17.7 \\
1953 & 3.4 & 2.1 & 5.5 & 1961 & 11.2 & 5.5 & 16.7 \\
1954 & 2.9 & 1.4 & 4.3 & 1962 & 11.6 & 6.5 & 18.1 \\
1955 & 6.4 & 5.8 & 12.2 & 1963 & 21.1 & $(10.5)$ & $(31.6)$ \\
1956 & 5.0 & 4.5 & 9.5 & 1964 & 15.2 & $(7.6)$ & $(22.8)$ \\
1957 & 1.7 & 1.1 & 2.8 & 1965 & 19.1 & 7.7 & 26.8 \\
1958 & 3.4 & 1.5 & 3.9 & 1966 & 12.0 & 3.8 & 15.8 \\
\hline
\end{tabular}

Note: Figures in parentheses are estimates assuming 0.5 dependents per worker.

Source: 1951-1962, Djawatan Penempatan Tenaga (quoted in Statistik konjunktur) ; 1963-1966, Direktorat Penjediaan dan Penggunaan Tenaga Kerdja, Departemen Tenaga Kerdja (unpublished data).

\section{MIGRATION IN THE OUTER ISLANDS}

Most of the numerically important population movements outside Java involve one of three ethnic groups: the Minangkabau, the Bandjarese, and the Buginese. We can state this in ethnic terms on the basis of the information provided by the 1930 census; for the present period we shall have to revert to birthplace data, however, Table 15 gives the major interprovincial movements into rural areas in the outer Islands (excluding migration from Java) recorded in 1961. In the provinces of West Sumatra, South Kalimantan, and South/Southeast Sulawesi, the main outflows--based on incomplete census data and estimates of the remaining figures--are shown in Figure 7.82 Relative to their 1961 populations, South Kalimantan appears predominant as a region of outmigration; if these estimates are accepted, about nine percent of its enumerated population was resident outside the province. The corresponding figures for West sumatra and

82. Estimates of outmigration from these three provinces are given in Appendix 2. For migration to other Outer Island provinces it is assumed that the proportion of inmigrants in the urban part of each province is the same as in the rural part. This procedure may introduce a bias, as south Sulawesi-born migrants appear to be concentrated in cities to a lesser extent than migrants from West sumatra or South Kalimantan. 
FIG. 7 : OUTMIGRATION FROM WEST SUMATRA, S \& SE SULAWESI, AND SOUTH KALIMANTAN BASED ON BIRTHPLACE DATA, 1961

(ESTIMATED TOTALS IN THOUSANDS)

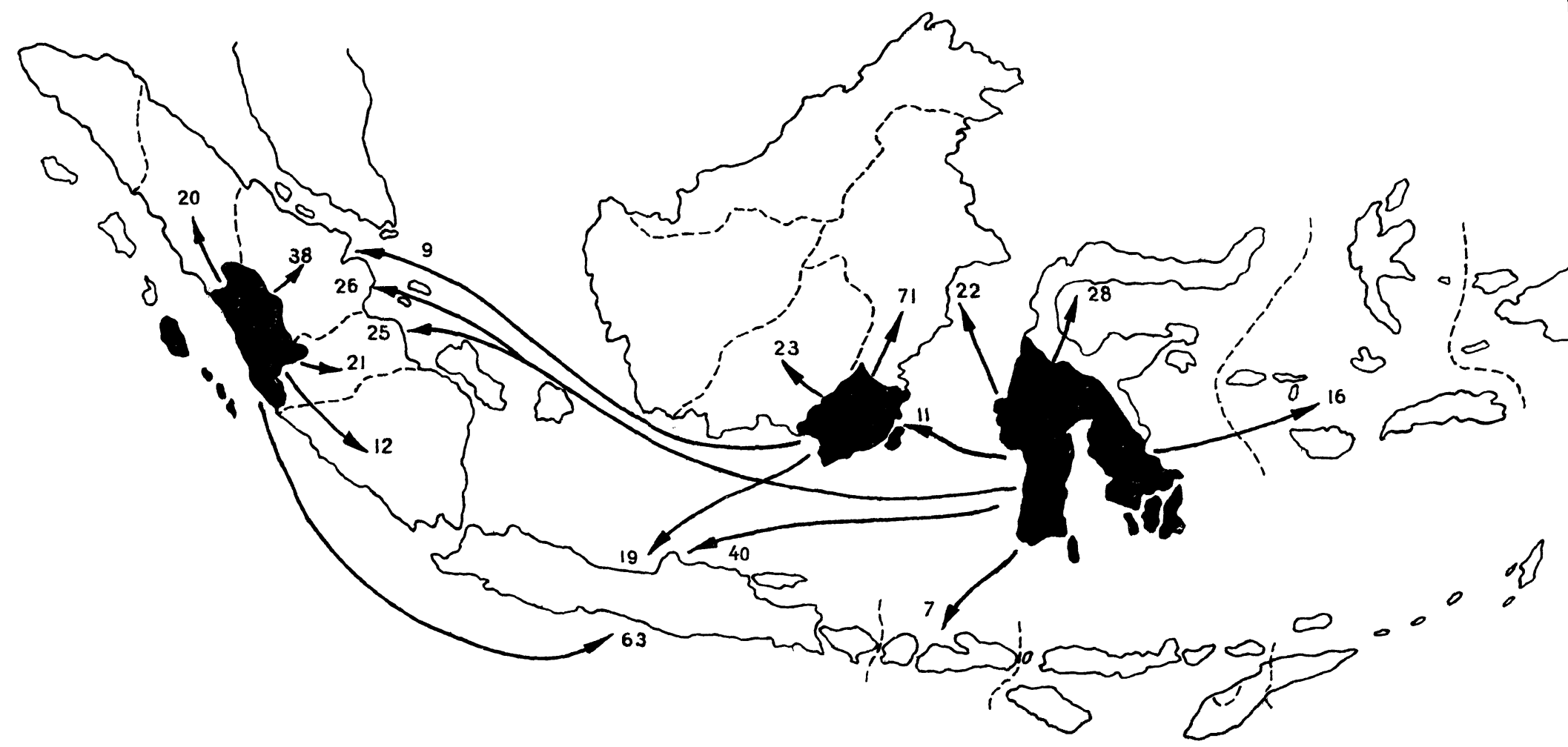

EXCLUDING MOVEMENTS OF LESS THAN 5000 TO ANY PROVINCE

SOURCE : BASED ON AVAILABLE CENSUS DATA, USING ASSUMPTIONS REFERRED TO IN TEXT 
South/Southeast Sulawesi would be 6.8 percent and 3.6 percent. 83

Table 15. Interprovincial Migration into Rural Areas of Outer Islands, Based on Birthplace Data, 1961a

\begin{tabular}{|c|c|c|c|c|c|c|}
\hline \multirow[b]{2}{*}{$\begin{array}{l}\text { Province of } \\
\text { Enumeration }\end{array}$} & \multicolumn{6}{|c|}{ Province of Birth } \\
\hline & $\begin{array}{l}\text { West } \\
\text { Sumatra }\end{array}$ & $\begin{array}{l}\text { North } \\
\text { Sumatra }\end{array}$ & Atjeh & $\begin{array}{l}\text { South } \\
\text { Kalim- } \\
\text { antan }\end{array}$ & $\begin{array}{l}S \& S E \\
\text { Sulawesi }\end{array}$ & Bali \\
\hline South Sumatra & 10,000 & & & & & 9,000 \\
\hline Djambi & 16,000 & & & & 19,000 & \\
\hline Riau & 35,000 & 7,000 & & 8,000 & 24,000 & \\
\hline West Sumatra & -- & 10,000 & & & & \\
\hline North Sumatra & 16,000 & -- & 15,000 & & & \\
\hline Atjeh & & 25,000 & -- & & & \\
\hline $\begin{array}{l}\text { Central Kal- } \\
\text { imantan }\end{array}$ & & & & 19,000 & & \\
\hline $\begin{array}{l}\text { South Kalim- } \\
\text { antan }\end{array}$ & & & & -- & 9,000 & \\
\hline $\begin{array}{l}\text { East Kalim- } \\
\text { antan }\end{array}$ & & & & 47,000 & 14,000 & \\
\hline$N \& C$ Sulawesi & & & & & 24,000 & \\
\hline $\begin{array}{l}\text { West Nusateng- } \\
\text { gara }\end{array}$ & & & & & 7,000 & \\
\hline Maluku & & & & & 14,000 & \\
\hline
\end{tabular}

a. Excluding movements of less than 5,000.

Source: Based on 1961 census, 90 percent sample.

Outmigrants from West Sumatra were recorded in considerable numbers in neighboring provinces, particularly in Djambi and Riau, the outer components of the former province of Central sumatra. There was also a nearly compensating reciprocal

83. In 1930, outmigrants from South/East Borneo (i.e., South, Central, and East Kalimantan) totalled 3.37 percent of the population, from West Sumatra 2.82 percent and from South/ Southeast Sulawesi 2.13 percent. These percentages were exceeded by Tapanuli ( 6.95 percent), and approached by Palembang, Bengkulu, and North/Central Sulawesi (respectively 2.63 percent, 2.95 percent, and 2.01 percent). Volkstelling 1930 (VIII), p. 95. 
movement between West and North Sumatra, but the main southward flow only reached Pasaman kabupaten (presumably from South Tapanuli), whereas most of the West Sumatrans went to Deli Serdang on the East Coast. If data for Medan were included the imbalance would probably be accentuated. Riau and to a lesser extent Djambi are major receiving areas for migrants from a number of other provinces: in Riau, nearly 20 percent of the rural populations of the kabupaten of Indragiri and Kepulauan Riau were born in different provinces or overseas. The province of North Sumatra, although absorbing large numbers of Javanese inmigrants, shows a small net outflow of its autochthonous population to Atjeh, Riau (Bengkalis), and even to Lampung. The exchange between North Sumatra and Atjeh has already been mentioned in reference to the Toba Batak migration and the Daud Beureuh rebellion.

Migratory currents in Kalimantan consist of a northward movement up the eastern coast into Pasir and Kutai kabupaten and movement into areas served by the Kapuas and Barito rivers in Central Kalimantan. A shortage of agricultural land in South Kalimantan has been suggested as a reason for migration 84 from that area, but it is also partly accounted for by the activities of the Bandjarese as river traders dealing with the interior in rubber and forest products such as rattan and damar. The east coast of Kalimantan has also attracted settlers from South/Southeast Sulawesi, Maluku, and East Nusatenggara. Before Confrontation many of these reportedly crossed the border into Sabah, where they found employment as estate workers. The flourishing smuggling trade between Sulawesi and Mindanao has at times involved East Kalimantan as a market for consumer goods, and this may be a further explanation for the size of the outborn community.

The net migratory flows estimated by the National Sample Survey (see above, Figure 1) do not always correspond with those just mentioned. The main difference--the absence of outmigration to Kalimantan and Sumatra from South-Southeast Sulawesi, a region expected on the basis of the census data to be a donor of migrants--has been noted earlier with the tentative explanation that many of the recent inmigrants were sulawesi-born. However, both this and the other apparent contradiction, the net migration from North Sumatra to Kalimantan, may equally likely be due to deficiencies in the survey. When the totals involved are less than a few thousands over the five year reference period, it is unreasonable to expect precision from a survey of this sort.

84. Monografi daerah: Daswati I Kalimantan Tengah (Djakarta: Biro Industrialisasi, 1962). In 1963, the agricultural population per hectare of farm land was 7.0 in Hulusungai but only 1.9 and 1.1 respectively in Pasir and Kapuas (although the proportion of sawah in Hulusungai was higher.) (Sensus Pertanian, 1963). 


\section{URBAN MIGRATION}

In the following brief treatment of movement to the cities, I shall discuss only a few aspects suggested by a simple analysis of the census and National Sample survey data by age, sex, marital status, and level of education; the emphasis will be on the characteristics of the migrants rather than on the urban growth 85 which their movement has caused. As in the previous sections the discussion is limited by gaps in the statistics: in general we know more about urbanization in Java than in other islands, but the omission of Djakarta from the National Sample Survey severely limits the usefulness of that study in describing recent urban migration on the island. Except in the case of Djakarta, census data on province of birth are of little assistance in making estimates, as large numbers of urban migrants do not cross provincial boundaries.

The importance of urban migration in terms of size relative to other population movements was roughly indicated in Table 3 . About one-quarter of all intervillage/intertown movements recorded for the period 1960-1964 were either rural-urban or intertown. Unfortunately the National Sample Survey does not distinguish between the two categories; the 1953 urbanization survey of Djakarta seems to be the only one to raise this interesting point. Heeren found that 68 percent of the sampled outborn male household heads in the capital had come from rural areas, the percentage being slightly higher among wartime migrants. There was considerable variation between regions of origin; about 78 percent of the migrants from West Java came from rural areas, while 54 percent did so from Central Java and 41 percent from East Java. Outside Java the sample size was too small for firm conclusions, but migrants to Djakarta from North Sumatra and Sulawesi seem to have been mainly from rural areas, while from Central sumatra and Kalimantan most were of urban origin. 86

85. For discussions of urban growth and urbanization see, among others, Nathan Keyfitz, "The Ecology of Indonesian Cities," American Journal of Sociology (LXVI, 4), 1961, PP. 348-354; Pauline D. Milone, "Contemporary Urbanization in Indonesia," Asian Survey (IV, 8), 1964, PP. 1000-1012; and W. F. Wertheim, "Urban Characteristics in Indonesia," in his East-West Parallels, pp. 165-181. For Djakarta, see also Heeren, op. cit., and Castles, op. cit. Much useful data on urban areas from the 1961 census which has not been published elsewhere is given in Milone's Urban Areas in Indonesia.

86. Heeren, $\mathrm{OP}$. cit., PP. 11, 27. The definition of "urban" is not stated but was probably wider than that used in the 1961 census. Considering the uneven distribution of ethnic groups in the city, the fact that Heeren's sample was not a random one may to some extent bias these percentages. 
We can give a more direct answer to the question of whether the destination of migration from particular regions tends to be urban or rural. Here we will consider the problem in conjunction with regional differences in the rates of inmigration to Java. If the available census birthplace data for Java and the estimates for West Java (see appendix) are pooled, the Outer Island provinces may be ranked according to the proportion of outmigrants from each (relative to its 1961 population) who were living in Java. The resulting order is shown in Table 16. Because of the possible errors in the West Java component, the series should be taken only as an approximate indication of the relative outmigration rates, however. 87 West Sumatra and Maluku stand out in this ranking as providing the largest proportions of outmigrants to Java, followed at some distance by North/ Central Sulawesi, South Sumatra, and East Kalimantan. At the other end of the scale, West Nusatenggara sent remarkably few migrants to Java, and Atjeh, Djambi, Bali, and West Irian show similar though less extreme immobility. These differences merit further study, but it might be prudent to wait for the final census results for Java before attempting this.

Table 16. Provinces of Outer Islands Ranked in Order of Estimated Numbers of Outmigrants in Java as Percentages of Their 1961 populations

\begin{tabular}{|c|c|c|c|c|c|}
\hline Rank & Province & $\begin{array}{l}\text { Outmi- } \\
\text { grants } \\
\text { in Java } \\
\text { (percent) }\end{array}$ & Rank & Province & $\begin{array}{l}\text { Outmi- } \\
\text { grants } \\
\text { in Java } \\
\text { (percent) }\end{array}$ \\
\hline 1 & $\begin{array}{l}\text { West Sumatra } \\
\text { Maluku }\end{array}$ & 2.7 & 9 & West Kalimantan & 0.9 \\
\hline 3 & $N \&$ C Sulawesi & 1.7 & 10 & $\begin{array}{l}\text { Riau } \\
S \& \text { SE Sulawesi }\end{array}$ & 0.8 \\
\hline 4 & $\begin{array}{l}\text { South Sumatra } \\
\text { East Kalimantan }\end{array}$ & 1.6 & & East Nusatenggara & \\
\hline 6 & South Kalimantan & 1.3 & 13 & West Irian & 0.6 \\
\hline 7 & North Sumatra & 1.2 & 15 & $\begin{array}{l}\text { Djambi } \\
\text { Bali }\end{array}$ & 0.5 \\
\hline 8 & Central Kalimantan & 1.0 & 17 & West Nusatenggara & 0.3 \\
\hline
\end{tabular}

Source: Based on 1961 census data and appendix estimates of migration into West Java.

87. If the West Java estimates are excluded, the ranking is only slightly modified. (The use of the 1961 populations as denominators is admittedly rather crude, taking no account of differences in growth rates--particularly in provinces experiencing significant inmigration--nor of changing patterns of migration over time.) 
Of the estimated total of approximately 400,000 Outer Islandborn residents of Jaya in 1961, almost 90 percent were enumerated in urban areas. Some provinces provided larger fractions of urban migrants than others: in East Java (the only extensive region allowing this analysis at present) migrants from Maluku, south and Central Kalimantan, North/Central Sulawesi, and East Nusatenggara were the most likely to be found in urban areas, those from Riau, Djambi, South Sumatra, and South/Southeast Sulawesi the least. However, it is quite likely that this order will be found to be different in Central and West Java. For one example, the Chinese, who may have formed a considerable part of the inflows from West Kalimantan, Riau, and Djambi, probably tended to settle in urban areas in regions other than East Java. In terms of absolute numbers the largest outborn groups in Java to be found in rural areas are those from South Sumatra, North Sumatra, and South/Southeast Sulawesi, which together comprise over half the total in this category.

In apparent contrast to the birthplace data presented above, the National Sample Survey showed a much greater proportion of the 1960-1964 inflow to Java being directed to rural areas, even when allowance is made for the exclusion of Djakarta. ${ }^{8} 8$ Assuming that the sampling errors have not materially changed the picture, the most likely of the possible reasons for this is that most of the inmigrants to rural Java recorded in the National Sample Survey were in fact born in Java. These would include returning contract laborers and their families, who could alone have averaged over 10,000 persons per year in the 1960-1964 period, and "failed" transmigrants. For regions outside Java, a similar comparison between the census and National Sample survey figures on the proportion of urban migrants cannot be made until the census returns for urban areas have been processed. The probable extent of 1960-1964 interprovincial migration within Java (which must largely depend on the accuracy of the estimates of migration to Djakarta derived in the appendix) is shown qualitatively in Figure 8. Where available, the census data support this picture.

\section{Characteristics of Urban Migrants}

Although urban migrants in Java originating from other parts of Indonesia are of considerable importance for various reasons, in sheer numbers they are hardly significant beside the local inmigrants. Similarly, migrants from Java to urban areas in the Outer Islands make up only a small part of the total number of urban migrants to these areas (see above, Table 3 ). In

88. Forty-one percent of the 1960-1964 inmigrants to Java (excluding Djakarta) went to rural areas; 24 percent if Djakarta is included (using appendix estimates of inmigration). 
FIG 8 DIAGRAMMATIC CHART OF NET INTERPROVINCIAL MIGRATION IN JAVA, AVERAGE 1960- 1964

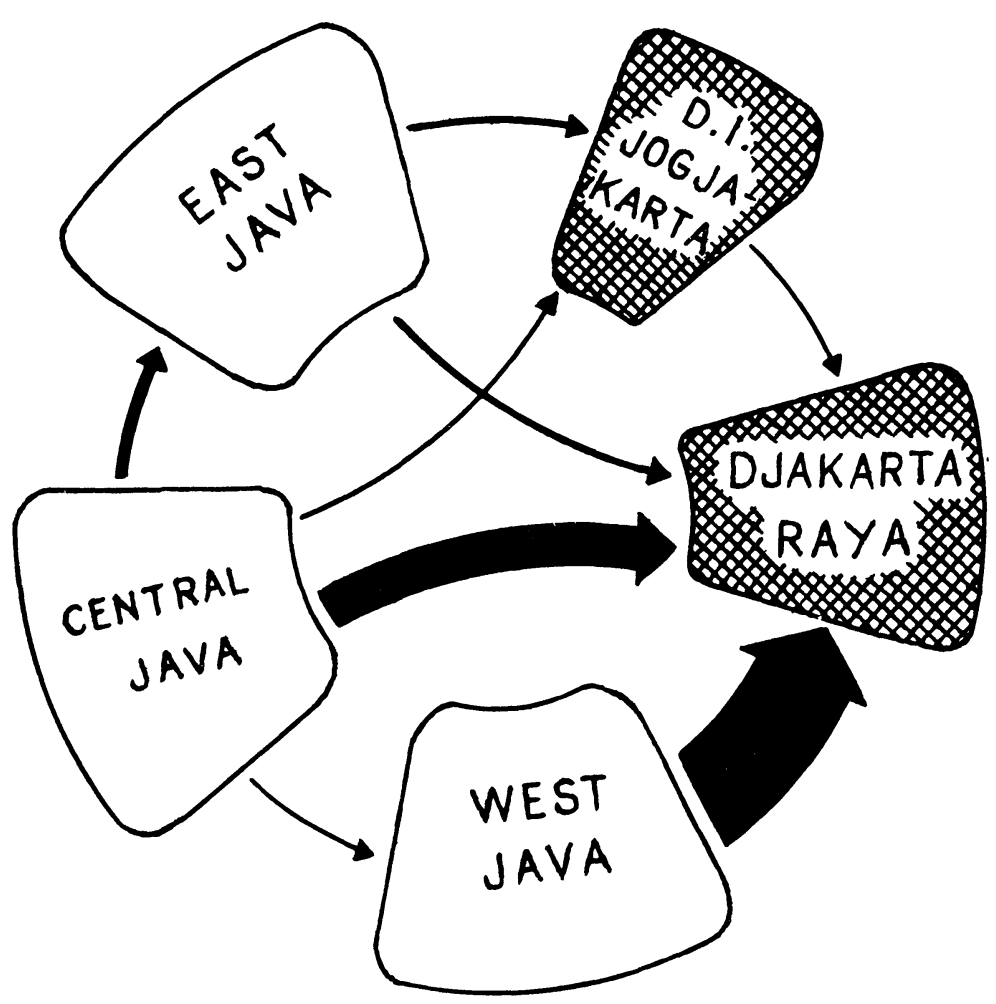

Regions of net inmigration

$\square$ Regions of net outmigration

Source: National Sample Survey, 1964/65 and estimates of inmigration to Djakarta Raya 
most cases urban migrants cannot be analyzed by place of origin, and thus the characteristics described here must be taken as referring mainly to short-distance migrants.

The age distribution of urban migrants (Table 17) shows marked variation from that of the general population of both rural and urban areas, and it also differs from the distribution of outmigrants from Java given in Table 10. There are more than twice as many urban migrants in the age group 20-24 than in the population as a whole, and there are also significantly larger numbers of the ages $15-19$ and 25-34. The proportions of young children and of older people among migrants are correspondingly smaller. Compared to outmigrants from Java, urban migrants include about twice as many people of ages 10-19, and the distribution is less strongly peaked in the middle age groups.

Table 17. Percentage Age Distributions and Sex Ratios of 19601964 Urban Migrants and Total Population of Rural and Urban Areas of Java and the Outer Islands, $1964^{\mathrm{a}}$

\begin{tabular}{|c|c|c|c|c|c|c|}
\hline \multirow[b]{2}{*}{$\begin{array}{l}\text { Age } \\
\text { Group }\end{array}$} & \multicolumn{3}{|c|}{ Java } & \multicolumn{3}{|c|}{ Outer Island } \\
\hline & Rural & Urban & $\begin{array}{l}\text { Urban } \\
\text { Migrants }\end{array}$ & Rural & Urban & $\begin{array}{l}\text { Urban } \\
\text { Migrants }\end{array}$ \\
\hline $\begin{aligned} 0 & -9 \\
10 & -14 \\
15 & -19 \\
20 & -24 \\
25 & -34 \\
35 & -44 \\
45 & -54 \\
55 & -\end{aligned}$ & $\begin{array}{r}32.7 \\
10.4 \\
6.9 \\
6.5 \\
15.6 \\
13.0 \\
8.3 \\
6.5\end{array}$ & $\begin{array}{r}29.4 \\
12.5 \\
8.5 \\
7.6 \\
15.0 \\
12.5 \\
7.8 \\
6.6\end{array}$ & $\begin{array}{r}19.2 \\
11.9 \\
12.0 \\
14.5 \\
21.1 \\
11.8 \\
5.7 \\
3.8\end{array}$ & $\begin{array}{r}34.5 \\
11.5 \\
8.4 \\
6.7 \\
13.5 \\
11.2 \\
7.3 \\
6.8\end{array}$ & $\begin{array}{r}31.9 \\
12.5 \\
11.1 \\
8.0 \\
13.9 \\
10.6 \\
6.5 \\
5.4\end{array}$ & $\begin{array}{r}22.5 \\
10.2 \\
14.6 \\
16.6 \\
15.2 \\
11.5 \\
5.7 \\
3.7\end{array}$ \\
\hline Unknown & 0.1 & 0.1 & -- & 0.1 & 0.1 & -- \\
\hline Total & 100.0 & 100.0 & 100.0 & 100.0 & 100.0 & 100.0 \\
\hline Sex Ratio & 976 & 940 & 894 & 997 & 997 & 1065 \\
\hline
\end{tabular}

a. Excluding Djakarta Raya, East Nusatenggara, Maluku, and West Irian in total distributions and as destinations of migrants. Urban migrants include interisland migrants to urban areas.

Source: Based on National Sample Survey, 1964/65.

The sex ratios given in the last row of Table 17 are reliable for the total populations, agreeing well with the census figures; but for inmigrants the errors, compounded by computing ratios, limit the validity of inferences. Nevertheless, the difference in the figures for urban migrants in Java and in the Outer Islands is surprising enough to warrant further examination. A feminine 
sex ratio for urban migrants does not of course mean that females migrate to the towns more readily than do males. It is largely explained by the correspondingly low sex ratios throughout Indonesia at the most mobile age groups, partly as a result of the war and revolution. ${ }^{89}$ If, for example, the number of outborn in urban areas is-taken as a percentage of the corresponding sex-age-specific population of their province of birth, male urban migrants appear to be relatively more numerous, even in Java.90 However, another likely partial explanation in the case of the National Sample Survey is underenumeration of the single male migrants in urban areas. The sex ratios for the autochthonous and outborn populations of Djakarta Raya, Jogjakarta territory, and East Java, the three provinces for which the census data are complete, show the expected progression in masculinity according to increasing distance from place of birth (Table 18). (A similar progression is seen for rural areas also, except for the apparent anomaly of inmigration into Jogjakarta Territory from Central Java. One explanation, in terms of "marriage migration," is mentioned below.) The instances of Djakarta and Jogjakarta, where all or many of the urban migrants are necessarily interprovincial, do not support the National Sample Survey picture, suggesting that if the latter is not simply wrong either urban migration to the smaller towns is predominantly female or the 1960-1964 pattern in Java is very different from the large-scale migration to the cities of the 1950's. The remarkably low sex ratios recorded for many towns in Java in 1961 would tend to support the former conclusion, 91 but in cases where the growth rate is also very low they

89. For a discussion of this phenomenon, whose existence has sometimes been disputed, see, among other sources, J. N. Bhatta, Source and Reliability of Demographic Data in Indonesia (Djakarta: Direktorat Topografi Angkatan Darat, 1961), P. 3. The 1961 sex ratios for all Indonesia were 990 at ages $15-19$ years, 796 at $20-24,859$ at 25-34, and 973 for all ages.

90. As an example, we can take the outborn population of Djakarta: in the age group 20-24 years the number of West Java-born males enumerated in Djakarta in 1961 amounted to 9.7 percent of the corresponding sex-age-specific population of West Java, while for females the percentage was only 7.7 percent; for the Central Java-born population at the same ages the equivalent percentages were 5.9 and 3.7 , and for Sulawesi-born 1.1 and 0.5 . (Computed from census worksheets and 1 percent sample tabulations.)

91. Based on preliminary census data, the sex ratio for all urban areas in Java in 1961 was 984 , but for urban areas other than kotapradja it was only 947 , lower than the average for all Java of 957 . Kotapradja with the lowest sex ratios were Modjokerto (895), Surakarta and Salatiga (902), Blitar (910), Probolinggo (913), Tegal (915), and Madiun (919). 
may be explained by a net outmigration of males directed to the larger cities.

Table 18. Sex Ratios of Population of Djakarta Raya, Jogjakarta Territory, and East Java by Location of Place of Birth Relative to Province of Enumeration, 1961

\begin{tabular}{|c|c|c|c|c|c|c|}
\hline \multirow[b]{2}{*}{$\begin{array}{l}\text { Region of } \\
\text { Enumeration }\end{array}$} & & \multicolumn{5}{|c|}{ Place of Birth } \\
\hline & & $\begin{array}{c}\text { Same } \\
\text { Province }\end{array}$ & $\begin{array}{l}\text { Contig- } \\
\text { uous } \\
\text { Province }\end{array}$ & $\begin{array}{c}\text { Else- } \\
\text { where } \\
\text { in Java }\end{array}$ & $\begin{array}{l}\text { Outer } \\
\text { Islands }\end{array}$ & $\begin{array}{l}\text { Over- } \\
\text { seas }\end{array}$ \\
\hline Djakarta Raya & & 983 & 1006 & 1145 & 1402 & 1691 \\
\hline D.I. Jogjakarta & $\begin{array}{l}\text { urban } \\
\text { rural } \\
\text { total }\end{array}$ & $\begin{array}{l}930 \\
940 \\
939\end{array}$ & $\begin{array}{r}1051 \\
845 \\
998\end{array}$ & $\begin{array}{l}1133 \\
1208 \\
1144\end{array}$ & $\begin{array}{l}2074 \\
1116 \\
1900\end{array}$ & $\begin{array}{l}2328 \\
1507 \\
2218\end{array}$ \\
\hline East Java & $\begin{array}{l}\text { urban } \\
\text { rural } \\
\text { total }\end{array}$ & $\begin{array}{l}933 \\
942 \\
941\end{array}$ & $\begin{array}{l}1242 \\
1272 \\
1257\end{array}$ & $\begin{array}{l}1356 \\
1264 \\
1320\end{array}$ & $\begin{array}{l}1447 \\
1378 \\
1436\end{array}$ & $\begin{array}{l}1812 \\
1648 \\
1778\end{array}$ \\
\hline
\end{tabular}

Source: Based on 1961 census data (final figures of provincial totals; 90 percent sample for rural areas; urban areas obtained as residuals).

The overall sex ratios of the Outer Island-born populations given in Table 18 obscure some interesting differences between provinces. In the case of Djakarta we can examine the birthplace data specified by age and sex. Computing the sex ratios for only a segment of the population, say the age group 20-34 years, should reduce the uneven effects of the war which probably distort the ratios at higher ages. As could be expected, there is some negative correlation between the excess of males at these ages and the number of children as measured by the proportion of the outborn population under ten years. Certain provinces, however, do not show this relationship. Among migrants born in West Sumatra, West Kalimantan and North/Central Sulawesi there is a relatively small proportion ( 10 percent or less). of children under ten, although the sex ratios are not abnormally high. Conversely, Riau and South/Southeast Sulawesi both show relatively large proportions of children and at the same time high sex ratios in the 20-34 year age group. As an example, the sex-age profiles of migrants from the two Sulawesi provinces are plotted in Figure 9. Various explanations in terms of the median age and family structure of migrants from these two provinces could account for the differences, but perhaps the most likely hypothesis is that migration from northern sulawesi was declining in the years prior to the census while from the southern half it was increasing. 
FIG. 9 : AGE DISTRIBUTIONS OF SULAWESI - BORN MIGRANTS IN DJAKARTA, 1961

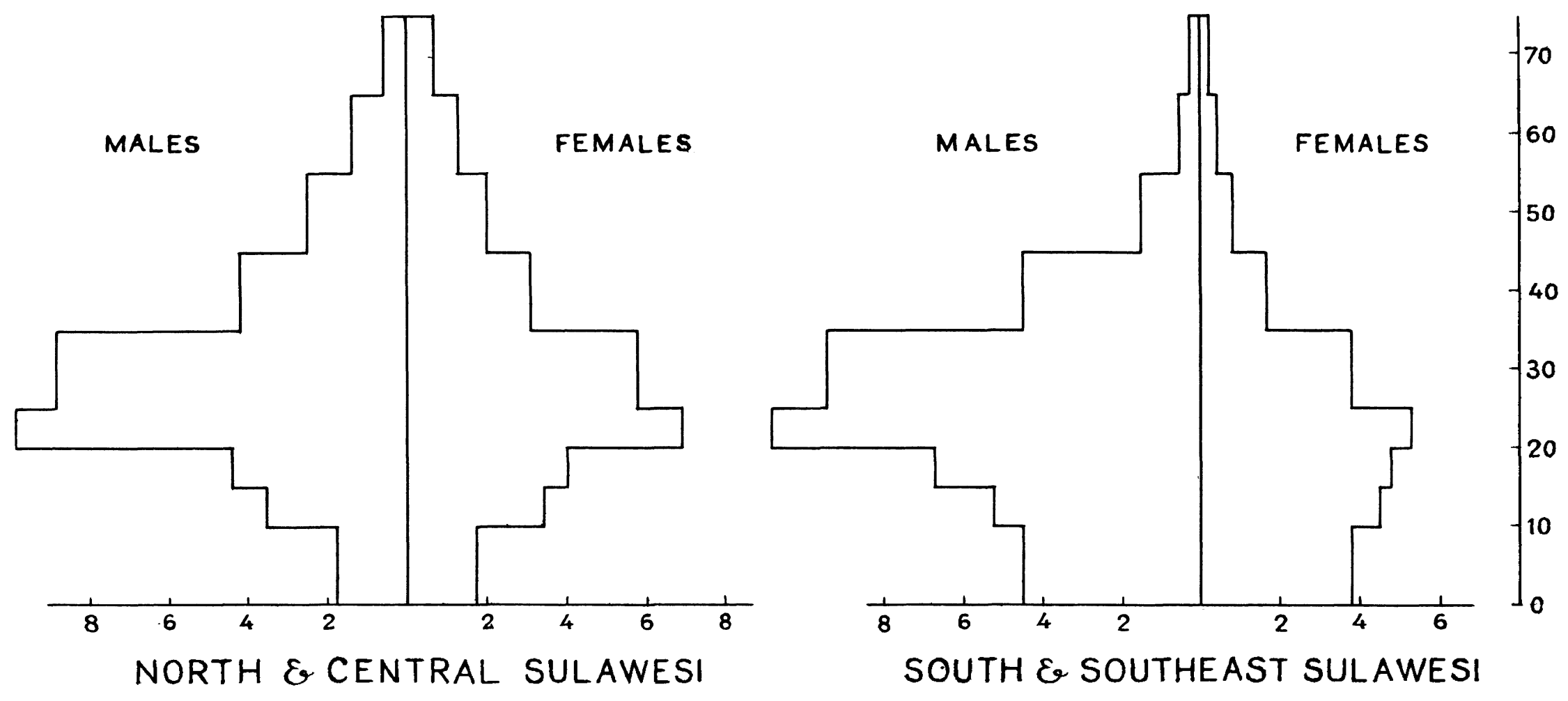

SOURCE : 1961 CENSUS, UNPUBLISHED DATA 
Data on the marital status of urban migrants in Java (excluding Djakarta Raya), compared with intervillage migrants and with the total urban and mural populations, are given in Table 19.

Table 19. Percentage of Ever-married in the 1960-1964 Inmigrant and 1963 Total Population of Java (of 10 years and over) by Age, Sex, and Urban/rural Area

\begin{tabular}{|c|c|c|c|c|c|c|c|c|c|}
\hline \multirow{3}{*}{\multicolumn{2}{|c|}{$\begin{array}{l}\text { Age } \\
\text { Group }\end{array}$}} & \multicolumn{4}{|c|}{ Urban } & \multicolumn{4}{|c|}{ RuraI } \\
\hline & & \multicolumn{2}{|c|}{ Males } & \multicolumn{2}{|c|}{ Females } & \multicolumn{2}{|c|}{ Males } & \multicolumn{2}{|c|}{ Females } \\
\hline & & $\begin{array}{l}\text { Inmi- } \\
\text { grants }\end{array}$ & Total & $\begin{array}{l}\text { Inmi- } \\
\text { grants }\end{array}$ & Total & $\begin{array}{l}\text { Inmi- } \\
\text { grants }\end{array}$ & Total & $\begin{array}{c}\text { Inmi- } \\
\text { grants }\end{array}$ & Total \\
\hline 10 & -14 & -- & 1 & 2 & 3 & -- & 1 & 4 & 5 \\
\hline 15 & -19 & -- & 2 & 30 & 27 & 12 & 6 & 71 & 56 \\
\hline 20 & -24 & 35 & 27 & 77 & 76 & 77 & 46 & 96 & 91 \\
\hline 25 & -29 & 71 & 68 & 85 & 92 & 91 & 84 & 98 & 97 \\
\hline 30 & - & 96 & 97 & 99 & 98 & 98 & 99 & 98 & 99 \\
\hline 10. & E over & 54 & 58 & 67 & 72 & 70 & 68 & 83 & 82 \\
\hline
\end{tabular}

a. Marital status of 1960-1964 migrants as at end-1964, total population as at end-1963. Djakarta Raya has been excluded from both categories.

Source: Based on National Sample Survey, lst and 2nd rounds, $1963 / 64$ and $1964 / 65$.

Since both the ages and marital status of the migrants are from the end of 1964, while those of the total population are from 1963 , there is possibly some bias stressing differences between the inmigrant and total populations. At any rate, it appears that when averaged over all ages ( 10 years and more) the proportion of those inmigrants to urban and rural areas who have ever been married does not greatly differ from the corresponding total population, although it is slightly less for both male and female urban migrants. The important differences appear in the specification by ages, particularly in the age groups 20-24 for males and 15-19 for the rural population of both sexes. Young migrants to urban areas (who include an unknown number of intertown migrants) show roughly the same marital pattern as the residents of urban areas; both have much smaller proportions of people who had been married at ages below 30 than the corresponding rural population. Only female urban migrants in the age group 25-29 show a larger proportion who had never married than appeared in the equivalent urban population. The comparatively large proportion of married persons in the mobile rural population, at 
ages less than 30 for males and 25 for females among recent intervillage migrants, can be interpreted as "marriage migration." of the 253,000 males and 323,000 females, ages 15-24, who were estimated to have moved over the previous five years, 116,000 of the males and 272,000 of the females (respectively 46 and 84 percent) were or had been married by 1964. The corresponding percentages in the whole rural population of that age group in 1963 were 24 and 75 . Although the proportion of those who had ever been married is similar at ages 30 and above, significant differences appear in the number who had been widowed or divorced: among female urban migrants the proportion of widowed or divorced was only 8 percent compared with over 30 percent in both the urban and rural populations. Conversely, male migrants in rural areas show a disproportionately high fraction ( 39 percent) of the widowed or divorced.

The final characteristic of urban migrants I should like to discuss is their level of education. In judging this, we are faced with the difficulty of distinguishing between migrants who move for reasons of education and those who are mobile as a result of their education; it is no great finding to demonstrate that high schools are located in towns. To minimize the problem we shall consider only the population above the age of schooling, say 25 years. The National Sample Survey indicates that of the 1960-1964 rural-urban or intertown migrants in Java (excluding Djakarta) of ages 25-44, 30.1 percent had passed junior high school (SMP) or its equivalent, 92 and 12.2 percent had also graduated from senior high school (SMA). The equivalent percentages for the whole population (including Djakarta, which lessens the contrast), were 15.5 and 6.3 percent. An even more striking comparison can be made in rural areas (see Table 20), where the mobile population of each age group contains many times more people with a high school education than does the whole rural population. The National Sample survey coverage is too small to allow any statement to be made about the mobility of university or academy graduates.

I have made no attempt here to describe the patterns of urban growth. Much detailed information on this could be extracted from the two censuses, with the hints of changes in the intercensal period provided by registration data, an almost unused but not entirely unusable source. The overall urban growth between 1930 and 1961 can give little indication of the current growth rates and is even less capable of distinguishing between natural increase and increase due to migration. Jones has estimated that 65 percent of the total 1930-1961 population increase in cities of 50,000 or above can be attributed to rural-urban migration and the subsequent natural increase of urban

92. Vocational junior high school, madrasah, mulo school, threeyear H.B.S., and so on. 
migrants. 93 It seems likely, however, that urban migration is at present a less significant component of urban growth than it was in the 1950's, both because of the relative stagnation of the economy and the "empty" cohorts in the age groups 15-19 and 20-24, from which urban migrants are mostly drawn. In the appendix discussion of migration to Djakarta it is assumed that the rate of inmigration had fallen off in the late 1950's. Of the other cities in Java, if the dubious official statistics of 1957 are compared to the 1961 census data, Surabaja and Surakarta show a drop in population, and Bandung, Jogjakarta, Pekalongan, Blitar, and Modjokerto show growth rates below the probable Java average.

Table 20. Percentage of High School Graduates in 1960-1964 Inmigrant and 1963 Total Population of Java (of 20 Years and Over) by Age

\begin{tabular}{cccccc}
\hline & \multicolumn{2}{c}{$\begin{array}{c}\text { Junior High School } \\
\text { or above }\end{array}$} & & \multicolumn{2}{c}{$\begin{array}{c}\text { Senior High School } \\
\text { or above }\end{array}$} \\
\cline { 2 - 3 } $\begin{array}{c}\text { Age } \\
\text { Group }\end{array}$ & Inmigrants & $\begin{array}{c}\text { Rural } \\
\text { Population }\end{array}$ & & Inmigrants & $\begin{array}{c}\text { Rural } \\
\text { Population }\end{array}$ \\
\hline $20-24$ & 22.6 & 5.8 & & 4.0 & 1.4 \\
$25-29$ & 18.2 & 2.7 & & 3.7 & 0.7 \\
$30-34$ & 9.2 & 1.0 & & 1.0 & 0.2 \\
$35-44$ & 5.5 & 0.6 & & -- & -- \\
$45-$ & 4.5 & 0.6 & & 0.4 & -- \\
20 E over & 12.4 & 1.7 & & 2.1 & 0.4 \\
\hline
\end{tabular}

Source: Based on National Sample Survey, lst $\varepsilon$ 2nd rounds, $1963 / 64$ and $1964 / 65$.

Much has been written on the likely consequences of the entry into the labor force of the first large cohorts of children born in the early .1950's. These groups are at the same time entering the period of their greatest spatial mobility. In the negative terms which may not be inappropriate to the situation, it remains to be seen whether the lack of opportunities in the cities will act as a sufficiently strong disincentive to urban migration as to balance the pressures of overpopulation in the countryside, or indeed whether such a condition of unstable equilibrium is at all possible.

93. G. W. Jones, "The Growth and Changing Structure of the Indonesian Labor Force," Bulletin of Indonesian Economic Studies ( 4 ), 1966, p. 58 . 
APPENDIX

1. Estimation of Recent Inmigration into Djakarta

As a consequence of the exclusion of Djakarta Raya from the results of the National Sample Survey of December $1964 /$ January 1965 there is no reliable basis for estimating net inmigration into the city in recent years. Even estimates of the rate of Djakarta's growth must be largely guesswork, as registration in the capital district is demonstrably far from complete. 1 We shall take as benchmarks the census-based estimate for the end-1961 population of 2.930 million and the end-1952 2 registered population of 1.782 million. The assumptions made to interpolate the growth between these years are arbitrary. The average annual geometric increase is 5.7 percent, but it is likely that the rate declined over this period as the great influx of migrants in the early 1950's slackened off. On the other hand, the rate of natural increase has probably risen. Keyfitz ${ }^{3}$ accepted 1.5 percent for the average annual natural increase in Java over 1949-1954, and there seems no reason for assuming a higher figure in Djakarta. But the 1962 Demographic Survey showed a natural increase for Djakarta, Surabaja, and Bandung in that year of 2.0 percent. ${ }^{4}$ Bhatta has calculated, on the basis of census data on the number of live births to women, who had been married, that the crude birth rate for Djakarta in 1961 was 45.6 per 1000,5 which would mean a natural increase probably

1. The registered population showed annual growth rates over the years 1951-1959 of respectively 16.0, 7.3, 0.8, 1.6, 1.2, $2.3,3.1,3.9,39.0$ percent (from data supplied by Kotapradja Djakarta Raya).

2. The kotapradja authorities consider registration in 1952 to have been the most complete of. any postwar year. Examination of recorded growth in subsequent years bears this out. Cf. Heeren, op. cit., p. 7 , who quotes a figure of 1.732 million for 1952; for our purposes the difference is negligible.

3. N. Keyfitz, "The Population of Indonesia," Ekonomi dan Keuangan Indonesia (VI, 10), 1953, p. 655.

4. Kannisto, 으. cit., p. 25.

5. J. N. Bhatta, An Estimate of Fertility Level of the Population of Djakarta by Polynomial Function (Djakarta: Direktorat Topografi Angkatan Darat, 1967), p. 9. Although at first sight this appears rather high, it should be remembered that the crude rate is partly a function of age structure and that Djakarta does not have a particularly unbalanced sex ratio (nor a much smaller than average proportion of married women) at reproductive ages. 
exceeding 2.5 percent. Assuming a linear rise in the rate of natural increase from 1.5 percent in 1953 to 2.0 percent in 1961 and a constant or slowly declining growth rate, we find that average annual inmigration would be close to 90,000. Even if the growth rate were assumed to have declined by four percentage points over this period (from 7.6 percent to 3.6 percent), the average annual gain from migration would still be about 85,000. In the latter case, however, the year-to-year number of inmigrants must have dropped from 110,000 in 1953 to around 35,000 in 1961, and this seems to be belied by the results of the first two demographic surveys of 1962 and 1963.

The Demographic Survey was only incidentally intended to provide data on internal migration, and its reliability is only as good as its accuracy in estimating natural increase and midyear population. ${ }^{6}$ The results for Java are shown in Table Al.

Table Al. Net Internal Migration in Java, Mid-1962 to Mid-1963, as Estimated by the Demographic Survey (population in thousands)

\begin{tabular}{|c|c|c|c|c|c|c|c|}
\hline \multirow{2}{*}{ Region } & \multicolumn{2}{|c|}{$\begin{array}{l}\text { Rate of } \\
\text { Natural } \\
\text { Increase } \\
\end{array}$} & \multicolumn{2}{|c|}{$\begin{array}{c}\text { Midyear } \\
\text { Population }\end{array}$} & \multirow{2}{*}{$\begin{array}{l}\text { Growth } \\
(5)-(4)\end{array}$} & \multirow{2}{*}{$\begin{array}{l}\text { Natural } \\
\text { Increase }\end{array}$} & \multirow[t]{2}{*}{$\begin{array}{l}\text { Net Migra- } \\
\text { tion } \\
(6)-(7)\end{array}$} \\
\hline & 1962 & 1963 & $\frac{10 p a}{1962}$ & 1963 & & & \\
\hline (I) & $(2)$ & $(3)$ & (4) & (5) & (6) & (7) & (8) \\
\hline Large cities & 19.9 & 20.7 & 5142 & 5544 & 402 & 104 & 298 \\
\hline $\begin{array}{l}\text { Other urban } \\
\text { areas }\end{array}$ & 23.0 & 25.0 & 4537 & 4629 & 92 & 109 & -17 \\
\hline Rural areas & 20.3 & 29.5 & 54670 & 54804 & 134 & 1361 & -1227 \\
\hline
\end{tabular}

a. Djakarta, Surabaja and Bandung.

Note: Column (3) calculated from 1963 estimated vital rates corrected by Kannisto's method (Kannisto, op. cit., p. 23); columns (4) and (5) calculated from recorded events as "living" + $\frac{1}{2}$ "dead" $+\frac{1}{2}$ "born living" $+\frac{1}{2}$ "moved in" + $\frac{1}{2}$ "moved out"; column (7)-applying simple average of 1962 and 1963 rates to mid-1962 population.

Source: Based on data in V. Kannisto, Population Increase in Indonesia (Djakarta: Central Bureau of statistics, 1963) and Kozo Ueda, The First and Second Demographic Surveys in Indonesia (Djakarta: Central Bureau of Statistics, 1965).

6 . The second round of the Survey showed a birth rate 12 percent higher and a death rate 13 percent lower than the first round twelve months previously, the differences being almost entirely in rural areas. [Kozo Ueda, The First and Second Demographic Surveys in Indonesia (Djakarta: Central Bureau of Statistics, 1965), P. 11J. While it is possible that the rates did vary as much as this, it is more likely the discrepancy is due to inadequacies in the surveys and to misreporting. 
They indicate that in 1962-1963 there was an annual average net inmigration into the large cities of Java (Djakarta, Surabaja, and Bandung) of almost 300,000 , a very small net outmigration from other urban areas, and over a million net outmigrants from rural areas. The improbability of this latter figure casts some doubt on the rest of the results, but it may be merely due to an underestimation of the 1963 rural population caused by underrecording of the "living" category in the second survey. Almost any assumption regarding the division of the large city inmigrants would allot over half to Djakarta, suggesting that in recent years net inmigration has considerably exceeded 100,000 per annum. However, to take a conservative figure and not rely too much on the Demographic Survey, we shall accept 100,000.7

In order to produce an estimate commensurable with the results of the second National Sample Survey on migration over the period 1960-1964 it is necessary to make a further assumption as to the degree of permanence of migration to Djakarta. In Table 4 above, it can be seen that among migrants to urban areas of Java other than Djakarta approximately half remain longer than five years; in the absence of evidence to the contrary we shall take this proportion of "leakage" to apply also to Djakarta. (It could, however, be argued that the fall-off is exaggerated due to the underreporting of movements occurring in the earlier years.) For simplicity's sake it will be assumed that leakage amounts to a constant fraction (one-eighth) of the initial inmigrants in each of the four years after their year of migration, with no further loss thereafter. ${ }^{8}$ It follows that the gross number of inmigrants in one year would be twice the net gain, while the number of people recorded as having moved in over the previous five years would be 7.5 times the net gain. Thus, annual net inmigration of 100,000 would require roughly 200,000 inmigrants per year and would form a pool of some 750,000 people who had migrated within the last five years.

The next step requires a similarly indirect use of available data: the distribution of inmigrants to Djakarta by region

7. There is, of course, no particular reason to suppose that the rate of growth of Djakarta's population has changed uniformly. Events such as the Darul Islam rebellion and the expulsion of the Chinese from rural areas probably caused abnormally large urban migration in certain years. Note also that the Demographic Survey and the National Sample Survey did not cover institutional households, in particular military barracks and closed military complexes.

8. It is possible to refine these assumptions in various ways, e.g., by taking an exponential decline in the annual cohort of migrants, but the grossness of the earlier assumptions and the likely sampling errors in the data make it unnecessary. 
of last residence. We cannot deduce this distribution from the National Sample survey results on urban migration in other provinces of Java because of the size of the sampling errors and also because of the uniqueness of the capital. There remain two other sources of data, Heeren's 1953 urbanization survey and the 1961 census, both of which give the distribution of the outborn population by birthplace. Because of the mass inmigration into Djakarta in the years immediately preceeding the 1953 survey ( 49 percent of the sampled migrants had arrived in the period 1950-1953, 73 percent in the period 1946-1953, most of them in only one stage), Heeren's results would seem to correspond more closely to a survey of current migration such as the National Sample Survey than do the later census data. But a comparison of the two distributions (Table A2) shows a decline

Table A2. Percentage Distribution of Birthplace of Outborn Population of Djakarta and Estimates of 1960-1964 Inmigration

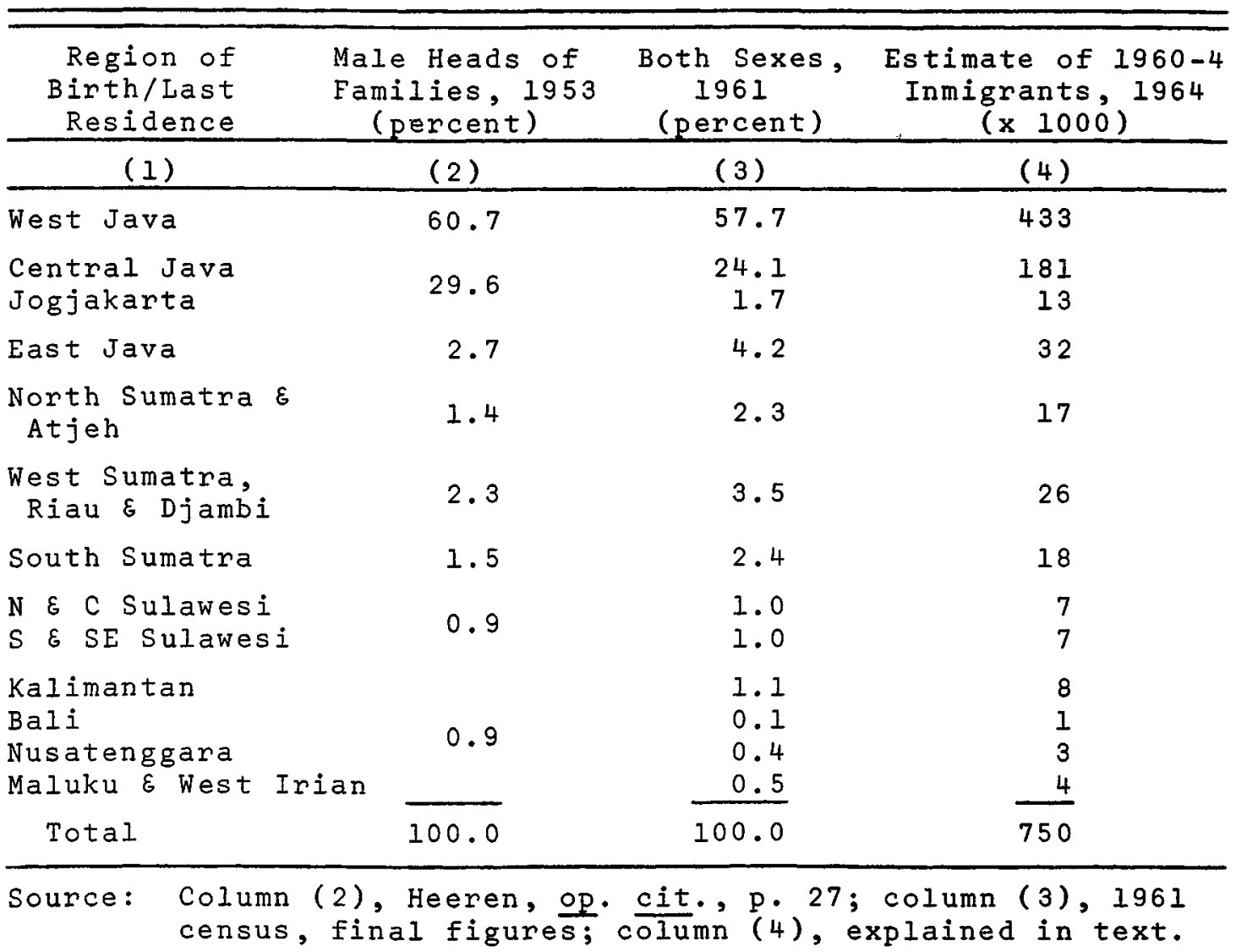


in the importance of West and Central Java as sending regions between 1953 and 1961, suggesting that the census may give a better approximation of 1960-1964 migration (although probably overstating the position of these two provinces). Allocation of place of origin according to the 1961 birthplace data gives the distribution shown in the last column.

As a check on what may be regarded as a rather dubious procedure, we can consider the other provinces of Java, where both census and National Sample Survey results are available: in Table A3 below it can be seen that there is in fact a reasonable measure of agreement despite the large sampling errors present in the National Sample Survey.

Table A3. Comparison of Census Birthplace Data and National Sample Survey data on 1960-1964 Migration (percentage distributions)

\begin{tabular}{|c|c|c|c|c|}
\hline \multirow{2}{*}{$\begin{array}{l}\text { Region of Birth/ } \\
\text { Last Residence }\end{array}$} & \multicolumn{2}{|c|}{ East Java } & \multicolumn{2}{|c|}{ Central Java } \\
\hline & Census & NSS & Census $^{a}$ & NSS \\
\hline West Java & 12.8 & 8.1 & 24.0 & 29.4 \\
\hline Central Java & 54.0 & 50.4 & & \\
\hline Jogjakarta & 7.0 & -- & 17.6 & 13.7 \\
\hline East Java & & & 32.4 & 23.5 \\
\hline Djakarta Raya & 1.7 & 6.5 & 3.4 & 4.9 \\
\hline Sumatra & 6.3 & 6.5 & 10.6 & 9.8 \\
\hline Kalimantan & 5.0 & 4.9 & 2.8 & 13.7 \\
\hline Sulawesi & 7.6 & 15.4 & 2.2 & 3.0 \\
\hline Bali $\&$ Nusatenggara & 3.8 & 4.1 & 2.8 & 2.0 \\
\hline Maluku & 1.8 & 4.1 & 4.2 & -- \\
\hline Total & 100.0 & 100.0 & 100.0 & 100.0 \\
\hline
\end{tabular}

a. Exluding urban areas other than kotapradja.

2. Estimation of the Outborn Population of West Java, 1961

The census birthplace data are complete or nearly complete for all of Java except the province of West Java. Here an estimate will be derived only for the Outer Island-born population. To obtain the overall total, we shall make use of the National Sample Survey data in a manner analagous to the use of census data in the previous section. The available totals are shown 
in column (2) of Table A4. Applying the current distribution of inmigrants [column ( 3 ), but excluding the estimate for Djakarta] to the known birthplace totals, we obtain an estimated total outborn population for Java of about 402,000, with

Table A4. Distribution of Outer Island-born Population in the Provinces of Java, 1961

\begin{tabular}{|c|c|c|c|}
\hline Province & $\begin{array}{l}\text { Outer Island- } \\
\text { born Population } \\
1961 \text { ( } 1000)\end{array}$ & $\begin{array}{l}\text { Distribution of } \\
1960-4 \text { Inmigrants } \\
\text { From Outer Islands } \\
\text { (percent) }\end{array}$ & $\begin{array}{l}\text { Estimates of } \\
\text { Outer Island- } \\
\text { born Population, } \\
1961(\mathrm{x} 1000) \\
\end{array}$ \\
\hline (1) & (2) & (3) & (4) \\
\hline $\begin{array}{l}\text { Djakarta Raya } \\
\text { Central Java } \\
\text { Jogjakarta } \\
\text { East Java } \\
\text { West Java }\end{array}$ & $\begin{array}{c}165.1 \\
46.3^{b} \\
16.3 \\
84.5 \\
--\end{array}$ & $\begin{array}{l}40^{2} \\
13 \\
4 \\
20 \\
23\end{array}$ & 89 \\
\hline Java & -- & 100 & 402 \\
\hline
\end{tabular}

a. Estimate as derived in Appendix 1.

b. Partly estimated.

Source: Column (2), 1961 census; column (3), National Sample Survey $1964 / 65$.

a subtotal of 89,000 for West Java. The breakdown of the West Java figure is based on the distribution for rural areas, a procedure which on the evidence of the other provinces of Java slightly overestimates the contribution of Sumatra and underestimates that of Nusatenggara and Maluku. The results are given in Table $A 5$.

Table A5. Estimated Distribution of Outer Island-born Population of West Java by Province of Birth, 1961

\begin{tabular}{lclc}
\hline \multicolumn{1}{c}{$\begin{array}{c}\text { Province of } \\
\text { Birth }\end{array}$} & $\begin{array}{c}\text { Number } \\
(\times 1000)\end{array}$ & \multicolumn{1}{c}{$\begin{array}{c}\text { Province of } \\
\text { Birth }\end{array}$} & $\begin{array}{c}\text { Number } \\
(\times 1000)\end{array}$ \\
\hline South Sumatra & 27 & East Kalimantan & 1 \\
Djambi & 3 & N E C Sulawesi & 5 \\
Riau Sumatra & 1 & S E SE Sulawesi & 10 \\
West Sumath & 11 & Bali & 1 \\
North Sumatra & 15 & West Nusatenggara & 1 \\
Atjeh Kalimantan & 2 & East Nusatenggara & 1 \\
West Kalimaliman & 3 & Maluku & 3 \\
Central Kalimantan & 2 & West Irian & 1 \\
South Kalimantan & 2 & Total & 89 \\
\end{tabular}


3. Estimation of Java-born Population in the Outer Is lands, 1961

The 90 percent sample census tablulations give reliable estimates of the Java-born population in the rural areas of Outer Island provinces. To obtain estimates for urban and rural areas, it is assumed that in each province the Java-born are found in the same proportion relative to the indigenous population in urban as in rural areas. Thus, the estimates of Java-born in rural areas are divided by the fraction of the provincial population enumerated in the rural areas.

Table A6. Estimated Java-born Population in Outer Island Provinces, 1961 (in thousands)

\begin{tabular}{lrlr}
\hline \multicolumn{1}{c}{ Province } & Number & \multicolumn{1}{c}{ Province } & Number \\
\hline South Sumatra & 960.4 & East Kalimantan & 23.2 \\
Djambi & 53.6 & N \& C Sulawesi & 9.3 \\
Riau Sumatra & 51.6 & S \& SE Sulawesi & 16.3 \\
West Sul & 9.9 & Bali & 8.7 \\
North Sumatra & 421.4 & West Nusatenggara & 2.5 \\
Atjeh Kalimantan & 31.3 & East Nusatenggara & 1.1 \\
West Kalimalimantan & 33.1 & Maluku & 4.7 \\
Central Kaliman & 4.2 & West Irian & -- \\
South Kalimantan & 15.8 & & \\
\hline
\end{tabular}

